\section{SAAAA \\ JOURNAL}

Open Access
Journal of Archaeology and Fine Arts in Southeast

Asia

Published by the SEAMEO Regional Centre for Archaeology and Fine Arts (SPAFA)

\title{
Terracotta Votive Tablets from Catubhummika Hngak Twin Monastery, Thaton
}

\author{
Khin $\mathrm{Ma} \mathrm{Ma} \mathrm{Mu}$ \\ Professor (Rtd) \\ Archaeology Department \\ Dagon University \\ Yangon, Myanmar \\ khinma2@gmail.com
}

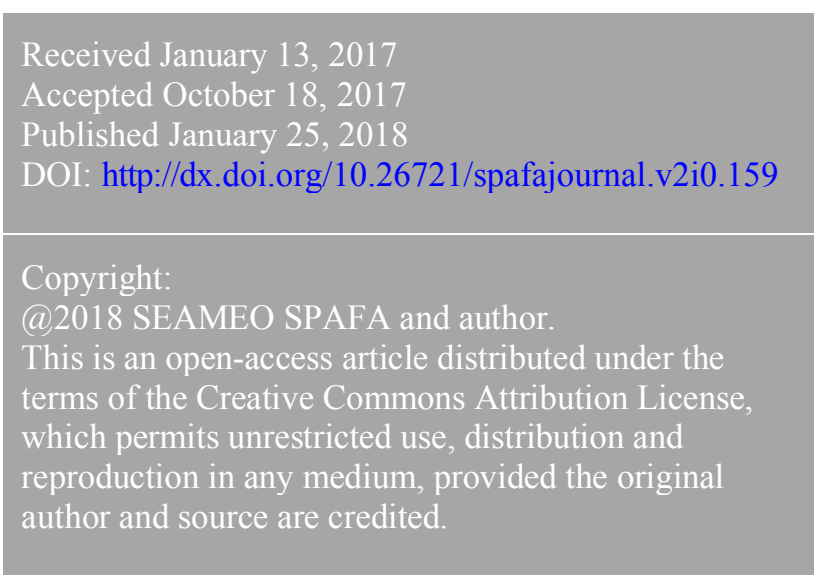

\begin{abstract}
Recent excavations from Stubhummika monastery, Thaton yielded over 2000 terracotta votive tablets, among them 1350 in good condition with others fragments. The study of these finds is based on the style of Buddha and Bodhisattava, decorative elements (stupas, sikhara, parasol and throne). These are compared with the contemporary tablets from Mon State, Śriksetra, Vesali and Bagan, and outside of Myanmar from India, central and peninsular Thailand and west Java to establish a comparative chronology. From this systematic approach, these tablets were divided into three groups: 1) Buddha (seated or standing Buddha, flanked by stupas), 2) Buddha Triad, and 3) Episodes of the Buddha. Their progression shows they are not be earlier than the $8^{\text {th }}-9^{\text {th }}$ century CE and not later than the $11^{\text {th }}$ century CE.
\end{abstract}

Keywords: Thaton, Buddhist art, religious culture, archaeology

\section{Introduction}

An assemblage of 1350 complete and 2000 fragmentary terracotta votive tablets was unearthed during 2015 rescue excavations at Catubhummika Monastery, Thaton $\left(16^{\circ}\right.$ $54^{\prime} \mathrm{N}$ and $97^{\circ} 22^{\prime} \mathrm{E}$ ) providing a significant addition to in situ data from Thaton (San Win 2015: 69, 85; Fig. 1). The assemblage is a significant addition to in situ data from which to understand the Buddhism of Thaton between the $8^{\text {th }}$ and $11^{\text {th }}$ centuries CE. 


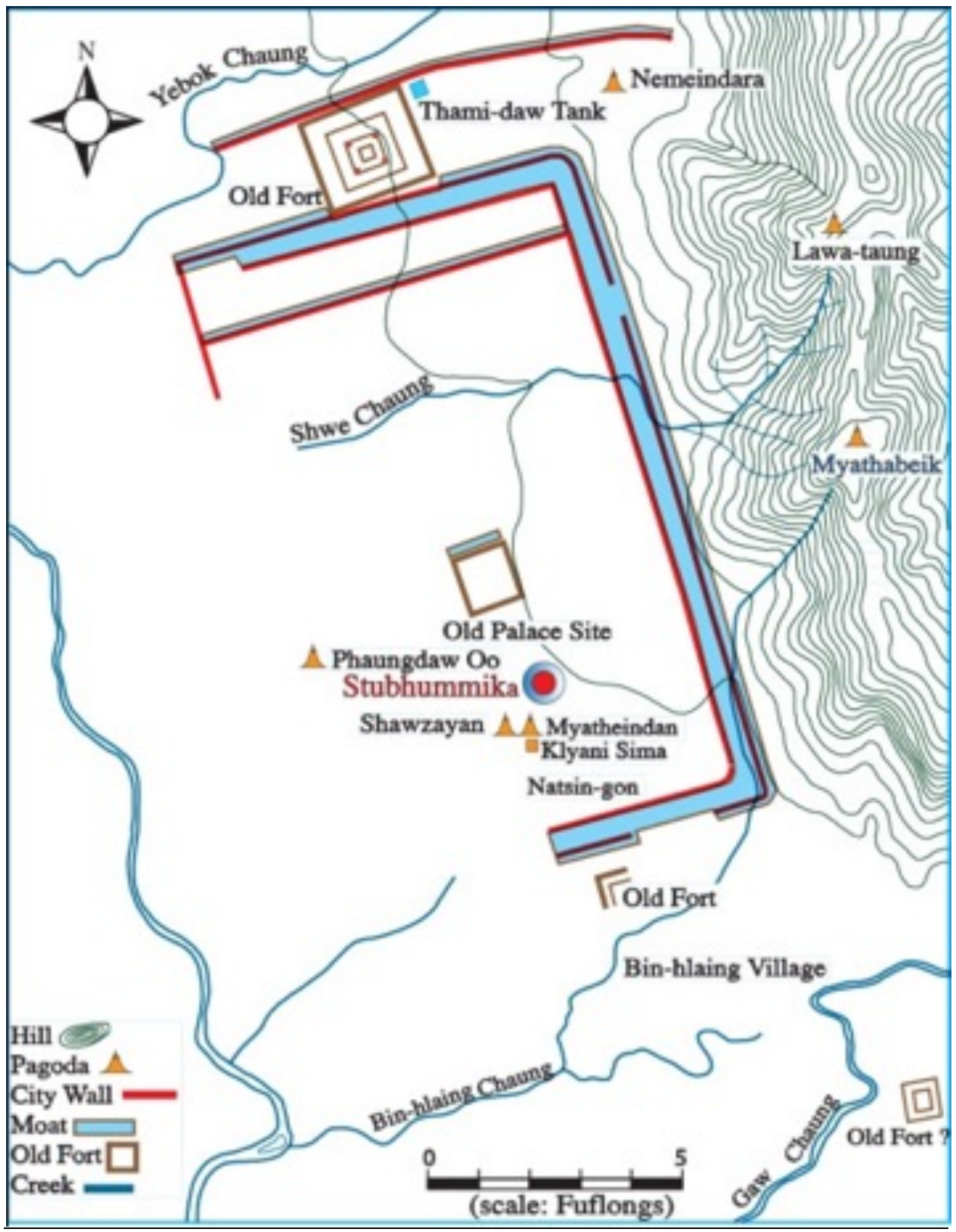

Fig. 1 Location of Catubhumikka Monastery, Thaton. Source: U San Win.

The votive tablets were discovered in 2015, when the abbot, Bhaddanta Tikkhañanna of Catubhummika monastery decided to build a corridor around the tomb of his deceased teacher Hngak-twin Sayatawkyi who passed away in $1910^{1}$. The corridor had an octagonal plan. A total of eight pits - CBK1 to CBK8 - were excavated under the corridor between May and November 2015. Pits CBK1, CBK2, CBK3 and CBK7 each measure 3.35 square meters while CBK2, CBK3, CBK4, CBK6 and CBK8 are 2.15 square meters. The votive tablets used in this classification came from pits CBK1, CBK2, CBK6 and CBK7. Within each pit, deposits were found at multiple

\footnotetext{
${ }^{1}$ Hngak-twin Sayataw kyi 'U Pandawa' (1831-1910 AD or 1193- 1272 ME) passed away in 1910 (ME 1271). His religious title was "Pañā dī pa kawi dha ja di sā pāmokkha tipitaka lañkāra" conferred respectfully by King Mindon in 1866 CE (ME 1228) during the Konbaung period.
} 
depths but further documentation was not possible as the renovation of the tomb proceeded (Tab. 1; Fig. 2).

\begin{tabular}{|c|c|c|c|}
\hline Date & $\begin{array}{c}\text { No of Votive } \\
\text { Tablets }\end{array}$ & \multicolumn{1}{|c|}{ Grid Square } & Depth \\
\hline 15-Jun-15 & 47 & CBK6-CBK7 & $137.16 \mathrm{CM}$ \\
\hline 15-Jun-15 & 46 & CBK1- CBK2 & $152.4 \mathrm{CM}$ \\
\hline 15-Jul-15 & 190 & CBK6 & $\begin{array}{c}152.4 \mathrm{CM}-213.36 \\
\text { CM }\end{array}$ \\
\hline 15-Jul-15 & 400 & CBK2 & $\begin{array}{c}152.4 \mathrm{CM}-213.36 \\
\text { CM }\end{array}$ \\
\hline 8-Aug-15 & 290 & CBK1 & $\begin{array}{c}152.4 \mathrm{CM}-213.36 \\
\mathrm{CM}\end{array}$ \\
\hline 15-Sep-15 & 400 & CBK2 & $\begin{array}{c}152.4 \mathrm{CM}-213.36 \\
\mathrm{CM}\end{array}$ \\
\hline 23-Nov-15 & 377 & CBK7 & $\begin{array}{c}152.4 \mathrm{CM}-213.36 \\
\mathrm{CM}\end{array}$ \\
\hline
\end{tabular}

Table 1 Votive Tablets per grid square and depth.

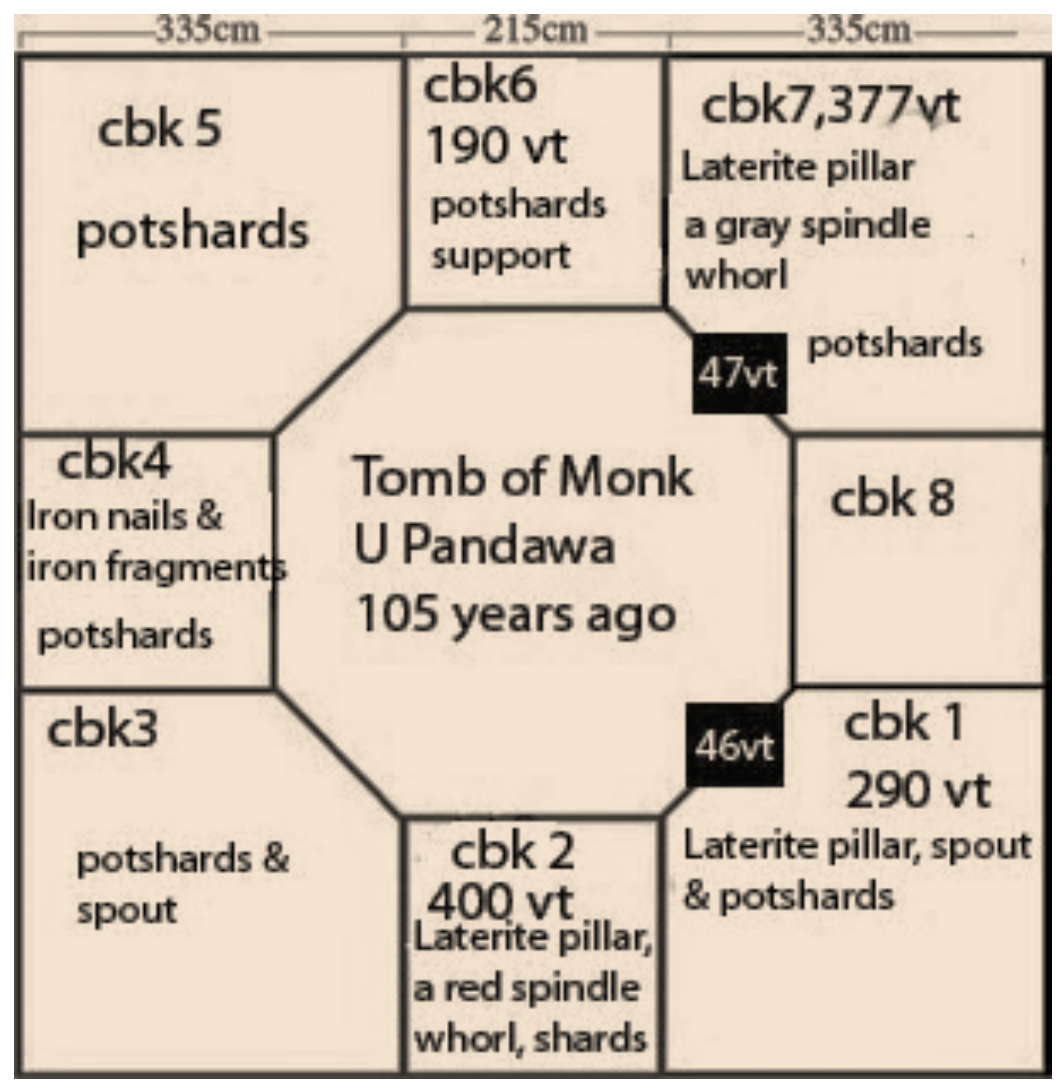

Fig. 2 Excavated finds from the Catubhummika (CBK) site in octagonal layout. Source: Bhaddanta Tikkañāna. 


\section{Other excavated objects and laterite pillars}

Potsherds were discovered in CBK1-4, 6 and 7, and iron nails and fragments in CBK 4 and 8. Finds from other pits include potsherds, libation jar spouts from CBK 1 and 3 and iron fragments all support the proposed $9^{\text {th }}-11^{\text {th }}$ century chronology. Another significant find was three laterite pillars excavated from CBK1, CBK2 and CBK7. The pillars which have the inner holes are associated with deposits of votive tablets. Each pillar appears to have been made to support a pile of votive tablets as the tablets were found heaped on top of, or placed in a cavity on average $10 \mathrm{~cm}$ deep made on top of the pillar.
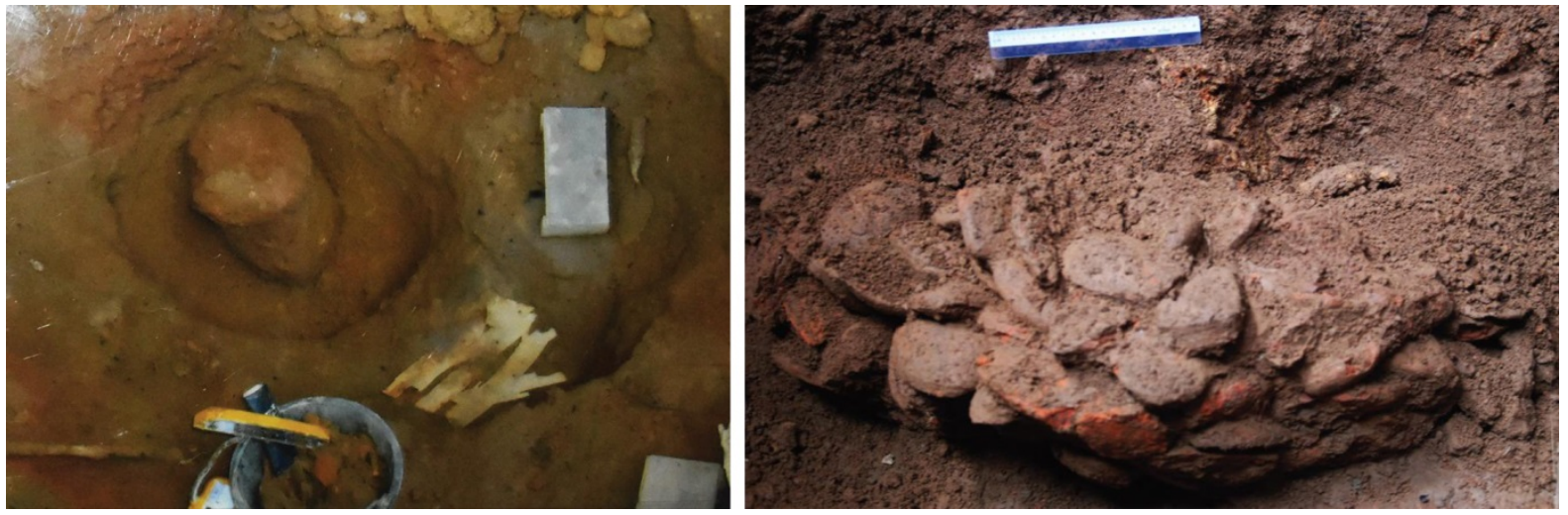

Fig. 3 Left: (Pillar support from CBK1, CBK2 and CBK7). Right: Heap of votive tablets on a laterite pillar support. Source: U San Win.

\begin{tabular}{|c|c|c|c|c|}
\hline \multirow{2}{*}{$\begin{array}{c}\text { No of Laterite } \\
\text { pillar }\end{array}$} & \multirow{2}{*}{ CBK 1} & \multirow{2}{*}{ CBK 2} & \multirow{2}{*}{ CBK 7} & CBK 7 \\
\hline & & & & Inner hole \\
\hline $\begin{array}{l}\text { Photograph } \\
\text { courtesy by } \\
\text { Bhaddanta } \\
\text { Tikkhañāna }\end{array}$ & & & & \\
\hline Measurement & $\begin{array}{l}\text { Height } 34.29 \mathrm{~cm} \text {, } \\
\text { Diameter } 30.48 \mathrm{~cm} \text {, Inner } \\
\text { hole depth } 11.43 \mathrm{~cm}, \\
\text { Diameter } 13.97 \mathrm{~cm}\end{array}$ & $\begin{array}{l}\text { Height } 35.56 \mathrm{~cm} \text {, } \\
\text { Diameter } \\
27.94 \mathrm{~cm}, \text { Inner } \\
\text { hole depth } \\
15.24 \mathrm{~cm}, \\
\text { Diameter } 10.16 \mathrm{~cm}\end{array}$ & $\begin{array}{l}\text { Height } \\
36.83 \mathrm{~cm}, \\
\text { Diameter } \\
26.67 \mathrm{~cm}\end{array}$ & $\begin{array}{l}\text { Height } \\
16.51 \mathrm{~cm}, \\
\text { Diameter } \\
10.16 \mathrm{~cm}\end{array}$ \\
\hline
\end{tabular}

Table 2 Laterite pillar supports found in CBK. Source: Bhaddanta Tikkañāna.

The pillars and libation jars indicate the previous use of this location for ritual purposes long before the tomb construction in 1910. The largest number of votive tablets was from CBK2 on the south with 400 , CBK7 on the northeast with 377 , CBK1 on the southeast with 290, CBK6 on the north with 190. An additional 47 tablets were found at the corner of CBK6 and 7 on the north, and 46 at the corner of CBK1 and 2 on the south. No tablets were recovered from any of the pits on the west or east, possibly because the image of the Buddha faced in this direction. 


\section{Votive Tablet classification}

The 1350 excavated votive tablets are divided into three groups:

1) Buddha Triad

2) Single Buddha and stupas

3) Episodes from the life of the Buddha

These groups are described below based on the size and shape of the tablets, the $m u d r \bar{a}$ and asana of the figures of the Buddha and bodhisattva and decorative details including the finial, arched pediment, stupas and the narrative scenes.

\section{Group 1: Buddha Triad}

Group1, Type 1
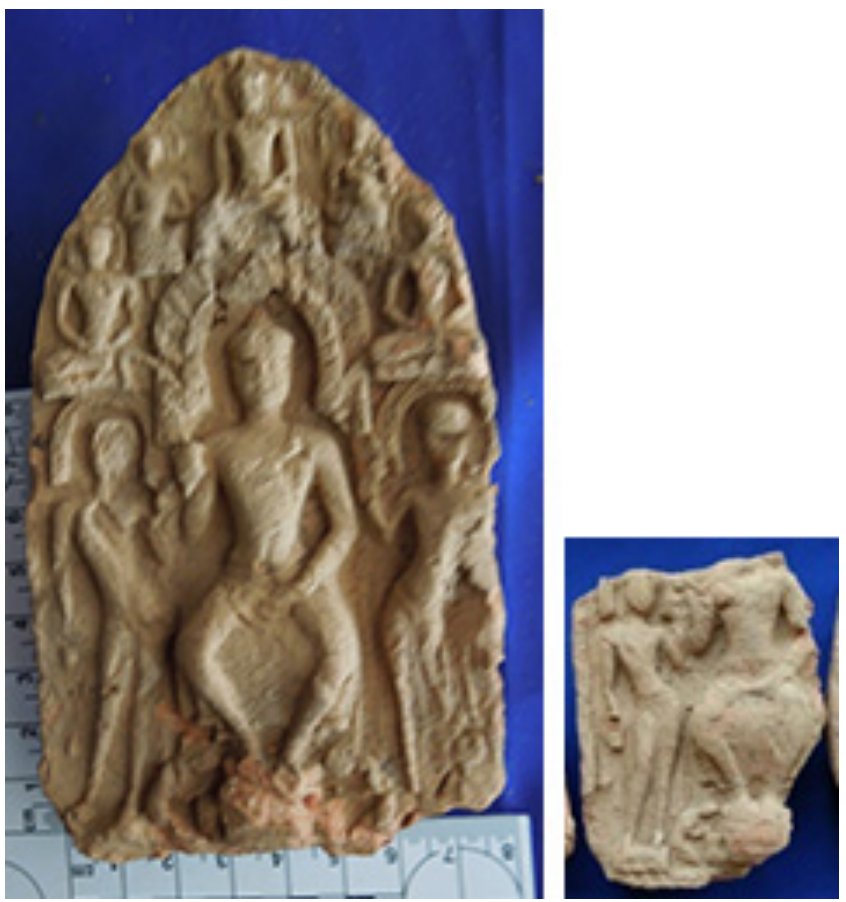

Fig, 4 Left: Type1 Buddha Triad with five DhyāniBuddhas [13 x 7.5 x 1.5cm]. Right: Fragment of Type1. Source: Khin Ma Ma Mu.

Type 1 has a rectangular base and a pointed top. There are nine tablets of Typelin good condition and eight broken ones among the excavated finds. The Type 1 tablets have two Panels depicting the five Dhyāni Buddhas on the upper part, and the Buddhist Triad and the two disciples at the Buddha's feet on the lower panel. All six Buddhas bear a halo and sit on lotus throne. At the upper panel, the topmost Buddha sits in dhyānāsana and bhümisparśamudrā flanked by a Buddha in dharmacakramudrā (vyākhyānamudrā) and dhyānāsana on each side. Under three seated Buddhas, there are two Buddhas in dhyānassana and dhyānamudrā (Samadhimudrā) at the level of the halo over the main figure.

The lower row is the Buddhist Triad with the Buddha (main figure) in bhadrāsana (pralambapadāsana) with the right hand in vitarka mudrā and left hand resting on the lap. The main figure is flanked by a pair of crownless standing Bodhisattva (Maitreya 
at the right side of Buddha and Avaokokiteśvarato the left) in tribangha pose with haloes. Their inner hands are raised in (?)abhayamudrā and outer hands are hanging down. At both sides of the Buddha's feet there are two kneeling figures in namaskāramudrā, probably the pre-eminent disciples Aggasāvaka Sāriputra and Moggalāna. This tablet is exactly the same as a broken tablet found in Sriksetra which is assigned to the date of $9^{\text {th }}-10^{\text {th }}$ century CE (Mya 1961: Vol. II: 28-29, Fig. 53).

Similar tablets (three seated Buddhas and Buddha Triad) were found in Vasali (Rakhine $8^{\text {th }}$ century CE, see Nyunt Han and Kyaw Oo Lwin 2015: 156), Kyaikkami ( $8^{\text {th }}$ century CE; Temple 1894), Winka (Thaton $6^{\text {th }}-7^{\text {th }}$ centuries CE, See Myint Aung 1999: 40-42, 52-53, Pl. VIII; Moore 2007: 198, Fig. on the top right, now at the Mawlamyine museum) and Kawgon (Mon State $6^{\text {th }}-7^{\text {th }}$ century CE; Mya 1961: Vol. I, Fig. 117), Thailand ( $8^{\text {th }}$ century CE, Cœdès 1926: 166, Pl. II; Chirapravati 1997: 22, Pl. 7; Krairiksh 1980: 123, Pl. 23) and West Java ( $7^{\text {th }}-8^{\text {th }}$ century CE, see Manguin and Indrajaya 2006: 248-249, Figs. 23-6; Revire 2012: 110-112).

This Type 1 tablet seems to be a new sub- type which was made by emulating the previous ones mentioned above. The styles and facial appearance and the body of Buddha in bhadrāsana post resemble those of the Pala period in India.Type 1 tablets are probably datable to the $9^{\text {th }}-10^{\text {th }}$ century CE. The style of bhadrāsana position was popular until $18^{\text {th }}$ century CE, and many such figures can be seen on the wall of Kawgun cave in Karan state, Myanmar.

\section{Group 1 Type 2: Three seated Buddhas}

The Type 2 votive tablet has a rectangular base and a rounded top. The Type 2 Buddha Triad tablets show three seated Buddhas. The central Buddha is in dharmacakramudrā and dhyānāsana seated on double lotus throne flanked by a nirmāna kaya or nimmita Buddha seated on double lotus throne on each side. They are probably seated in dhyānāsana with dharmacakramudrā. This episode probably represents the Episode of the Twin Miracle or the First Sermon, the latter because some votive tablets with the Eight Episodes of Buddha's life include this scene. Two sub-types are shown below with the different arrangement of figures below the throne noted in the text.

Under the throne there seems to be four or five persons. The middle one is a crowned Bodhisattva seated in Rajjalilāsana with the left hand raised and palm upward, and the right hand resting on the knee. The person at the left corner of the tablet is probably Sakti (the consort of Bodhisattva) or a Bodhisattva kneeling on one leg and the other one is raised. The left hand is raised on the left knee with palm upward in the same $m u d r \bar{a}$ as the Bodhisattva in the middle with the right hand bent into chest (discussion posture?). The other person is standing beside the middle Bodhisattva and the adjoining two figures also appear to be standing and sitting. There is a single lotus line at the base of votive tablet. The styles of these figures alternate in their placement between left to right (Type 2A) and in the opposite direction (Type 2B).

Group 1, Type 2 

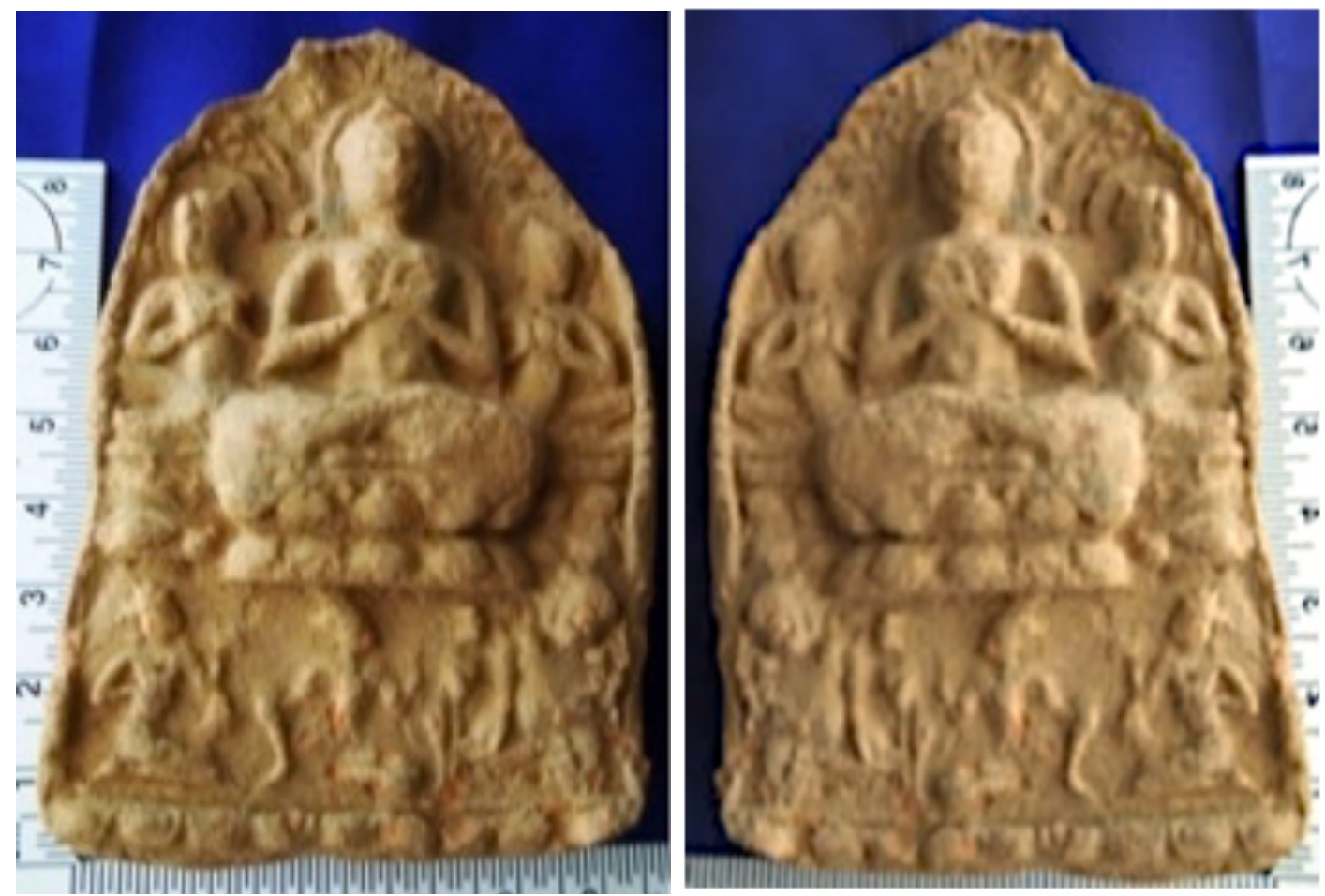

Fig. 5 Left: Type 2A [8.5 x6 x 1.5 cm]. Right: Type 2B. [9 x 6.3 x $1.5 \mathrm{~cm}]$. Source: Khin Ma Ma $\mathrm{Mu}$.

Their styles and postures are similar to the Bodhisattva figures of the tablets from Śriksetra (Mya 1961: Vol II, 17, Fig. 16, 84; Duroiselle 1931: 130-131, Figs. 2, 4, 8). U Mya suggested that there might have been connections between Śriksetra and Nalandain Bihar, India as well as Thailand and the Malay Peninsula due to the letter 'Sri nalandaya' (See Mya: Vol. II, 36-37, Fig. 85). They are presumed here to date to the $9^{\text {th }}-10^{\text {th }}$ century CE based on the same asana and mudra $\bar{a}$ of Buddha and Bodhisattva on votive tablets from Śriksetra.

Group 1, Type 3: Crowned Sakyamuni Buddha or crowned Nirmāna Buddha

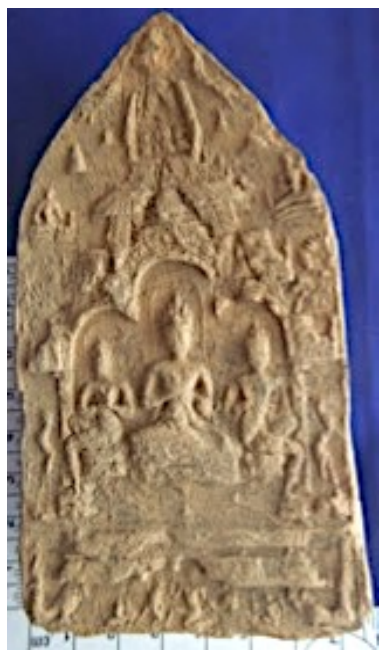

Fig. 6 Group 1, Type 3 Three Nirmāna-kāya crowned Buddhas, 9th-10th century CE [12 x 6.7 x 1.5 $\mathrm{cm}]$. Source: Khin Ma Ma Mu. 
The Type 3 votive tablet has a rectangular base and pointed top. It can be compared to one with a rim from Śriksetra $\left(9^{\text {th }}-10^{\text {th }}\right.$ century CE) (Mya 1961: Vol. II, 33, Fig. 73$)$. The tablet has a htupika (stupika) finial with an amalaka (stone disk with ridges; Myanmar call this 'Phayon tone') on the apex of the sikhara. It seems that a ceti is under the sikhara. There is a flying deity and two miniature stupas on each side of the sikhara. Under the flying deities on both side of sikhara, the Bodhi tree is depicted. Besides the pediment, each Byāla or lion is depicted in standing profile. At the base, under the throne, there is a deer at the both corners. A further five persons are in standing and sitting positions, probably Māra's army, often seen at Catubhumikka votive tablets with the Enlightenment of the Buddha and Buddha Triad.

A crowned Buddha sits in dharmacakramudrā and dhyanāsana between two crowned nirmāna Buddha in dharmacakramudrā and sitting with lalitāsana-one leg raised and one hanging under the large trefoil arch (See Luce 1969-70: Vol. I, 174). These three Buddhas sit on the double lotus throne and are front-facing. Inside the upper śikhara are also miniature three seated Buddhas similar to the main three figures inside the trefoil arch. These three Buddha figures probably represent the Nirmāna-kāyaSakyamuni Buddha. According to the Mahāyāna Buddhism, the Tri-Kāya or three kinds of Bodies of the Buddha are explained as follows:

...it is believed that Buddha has three kinds of body. (1) Dharma$k \bar{a} y a$ : This is 'Dharma Body or Body of Reality'which is formless, unchanging and transcendental. Its synonyms are Suchness (Tathatā) and Voidness (Suñ̃ata). (2) Sambhoga-kāya: Amitābhā Buddha etc. who presides over the Pure Land is the 'Celestial Body of Enjoyment'. (3) Nirmāna-kāya: In order to benefit the world, a Buddha incarnates Himself into the human body. Sakyamuni Buddha and so on, who had attained Buddhahood, are the 'Incarnated Body' (U Nyanawara 2014:47).

Further comparisons can be made to a triad on the upper part of the Trap, an old Mon inscription of King Makuta (circa $1015 \mathrm{CE}$ ) found at the Shwesayan pagoda in Thaton (Luce 1969-70: Vol. I, 174) and Śriksetra as well (Mya 1961: Vol. II, 33, Fig. 73). However, the disciples flanking the Buddha from the Trap inscription are in namaskāramudra which are different to those from the figures of this type. Professor Luce mentioned the mudras of disciples in dharmacakramudrāas follows.

...similarly shows a crowned Buddha seated crosslegged in dharmacakramudrā. On each side, in pralambapanāsana, sits sideways but face front a nirmāna Buddha, crownless, also in dharmacakramudrā. The scene should be the Twin Miracle, but below the lotus seat appears the Wheel, with Deer on each side, i.e. the First Sermon!" (Luce 1969-70: Vol. I, 174)

It is supposed to be of the episode of the First Sermon due to the inclusion of the wheel and deer. The date of the tablet as Śriksetra assigned by U Mya is $9^{\text {th }}-10^{\text {th }}$ century CE, before the reign of King Aniruddha, Bagan. The suggestion of Mahayana 
patronage of the king during the $10^{\text {th }}$ century CE is supported by these tablets (Mya 1961: Vol II, 33, Fig. 73).

Group 1, Type 4: Enlightenment (4A) and First Sermon(4B)
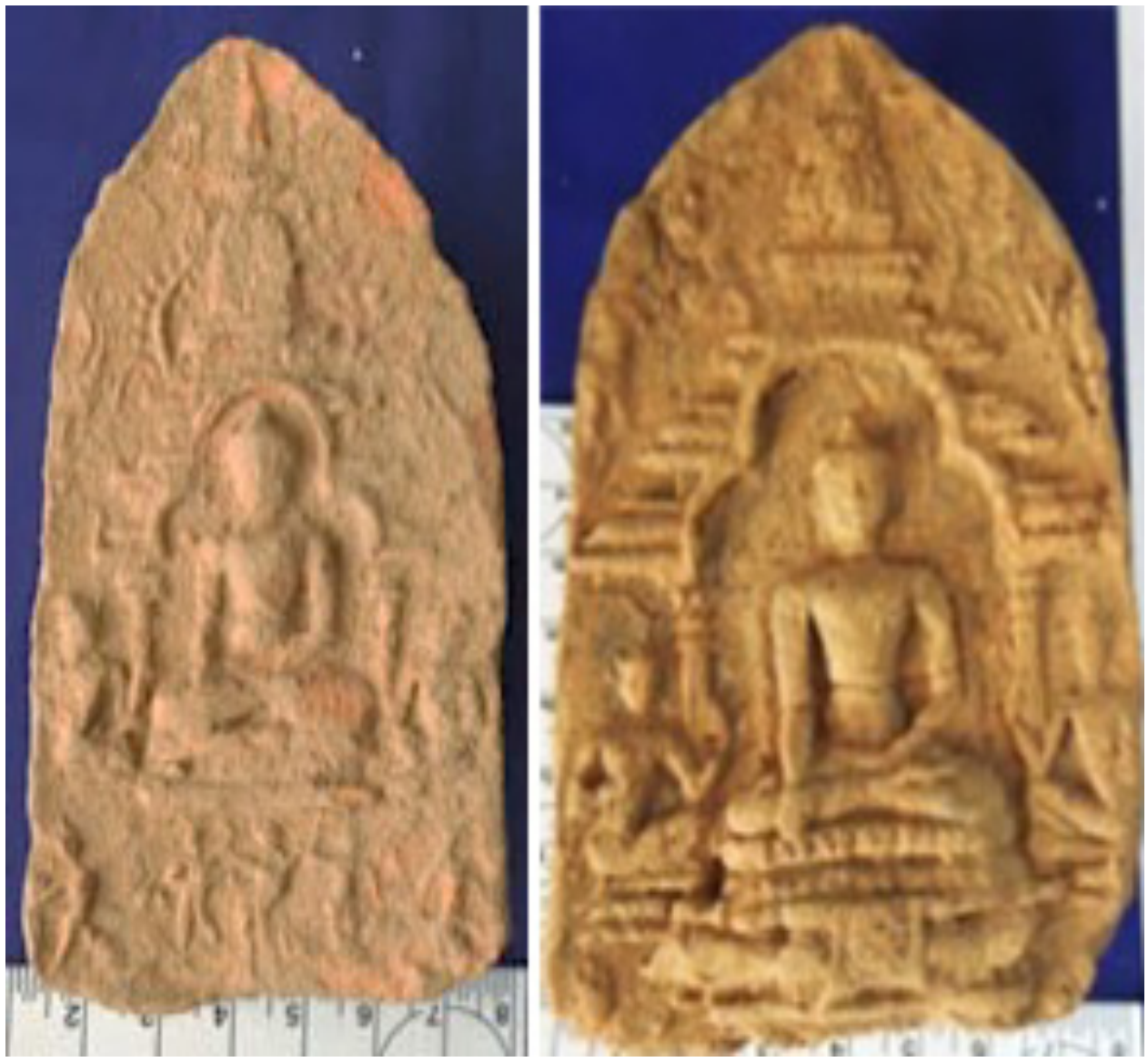

Fig. 7 Left: Type 4A [11x6 x 2.5 cm]. Right: Type 4B [8 x 4.5 x 2 cm]. Source: Khin Ma Ma Mu.

The Type 4 votive tablet has a rectangular base and an almost pointed top. Type 4A shows the Enlightenment of Buddha and 4B depicts the First Sermon. Both Type 4A and 4B depict the Mahayanist Buddha Triad. Another difference between the two types is the depiction of the daughters of Māra under the double lotus throne of Buddha and Bodhisattva in Type 4A and the dharmacakra wheel under the double lotus throne of Type 4B. The main Buddha image of both Type 4A and 4B sits in dhyānāsana and bhümisparśamudrā inside the trefoil arch with three receding roofs surmounted by a Bodhi śikhara and a stupa finial. Type 4A has a longer finial than type 4B.

At each side of the Buddha is a Bodhisattva possibly, Maitreya and Avaokokiteśvara (Lokanātha), in virāsana (one knee raised and the foot locked in the bend of the other, see Than Tun 1978: 173, Fig. 18) with the right or left hand raised on the knee in an unclear mudra with the other hand bending onto chest. On the sides of the sikhara are the branches and leaves of the Bodhi tree. A harmika (square shaped relic chamber of the Sri Lankan type) is surmounted by a sikhara and a top finial. Type 4A has a curving of floral pattern around the sides of sikhara. According to the style of the 
Maha Bodhi sikhara and Bodhisattvas the tablet may be dated to the $9^{\text {th }}-10^{\text {th }}$ century CE.

Group 1, Type 5: Buddha on Khou nan: gjou: throne flanked by Bodhisattva

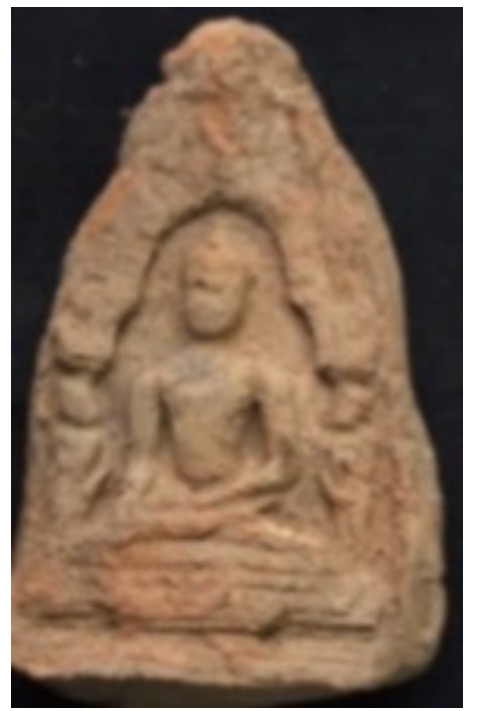

Fig. $8 \quad[7.5 \times 4.5 \times 2 \mathrm{~cm}]$. Source: U San Win.

The shape of Type 5 is a rectangular base and almost pointed top. The votive tablet seems to have not been baked well due to the irregularity of its coloration. The Buddha is seated in dhyānāsana and bhümisparśamudrā on a Khou nan: gjou: throne (the projecting corners on throne). The type is unlike other thrones of votive tablets found in Catubhummika monastery. The Buddha is inside the niche surmounted by a sikhara and top finial. The Buddha is flanked by two standing Bodhisattva facing inwards with outer hand in (?)mahākārunikamudrā and the inner one hanging. Comparing the throne and sikhara to that of Bagan, this style is probably dated to the $9^{\text {th }}-10^{\text {th }}$ century CE before King Aniruddha of Bagan.

\section{Group 2: Buddha and stupas}

Group 2 is described first in relation to the Buddha image and second by the finial and type of calac (pediment). There are three types of finial on the niche of the Tamkai (rear section of the throne of the Buddha): umbrella, stupa and sikhara-type.

1. Umbrella (chattravali) finial

1.1. Umbrella finial supported by a long pole, $9^{\text {th }}-11^{\text {th }}$ century CE in Myanmar, Group 2, Type 4.1

1.2. Umbrella as the top finial, $7^{\text {th }}-8^{\text {th }}$ century $\mathrm{CE}$ in India, $9^{\text {th }}-12^{\text {th }}$ century $C E$ in Myanmar, Group2, Type 4.2

2. Stupa finial on harmika (Relic chamber type), (?) $9^{\text {th }}-11^{\text {th }}$ century CE, (Group 2, Type 5)

3. Sikhara finial with amalaka

3.1. Sikhara on stupa (Group 1, Buddha Triad, Type 3; another example from Śriksetra $9^{\text {th }}-10^{\text {th }}$ century CE, see Mya 1961: Vol. II, 33, Fig. 73) 
3.2. Sikhara finial with amalaka; sikhara or spire on the arch pediment with amalaka between the sikhara and top finial of Bodhi calac; $10^{\text {th }}-11^{\text {th }}$ century CE (Group 2, Type 6.1 to 6.5)

\section{Group 2, Type 1: Seated Buddha}

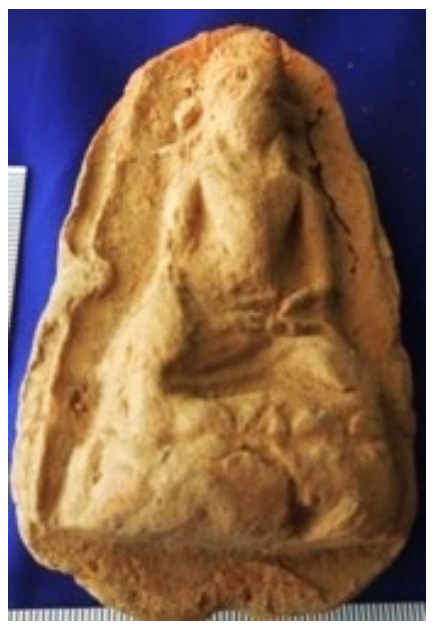

Fig. $9 \quad[9 \times 6.5 \times 1 \mathrm{~cm}]$. Source: Khin Ma Ma Mu.

A single image of the Buddha in dhyānāsana and bhümișparśamudrā sits on a double lotus throne. The face and hair knot is unclear. It may be a local product, indicated by the fuzziness of the image, or this may be due to weathering. This tablet seems to be dated to the $10^{\text {th }}$-early $11^{\text {th }}$ century CE.

Group 2, Type 2: Standing Crowned Buddha

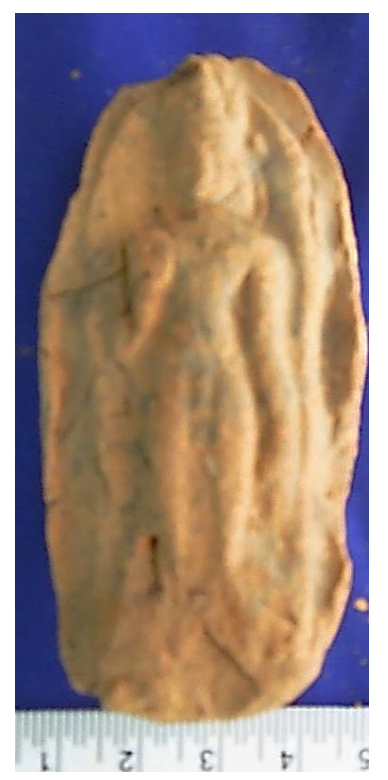

Fig. 10 [10 x 4 x 1.7cm]. Source: Khin Ma Ma Mu. 
The Group 2, Type 2 tablets are oblong and ovoid, featuring a standing crowned Buddha is surrounded by halo with right hand in abhayamudrā and left hand hanging. The depiction is probably of Buddha's Descent from Tâvatims $\bar{a}$ Hs $\bar{a}$. The depictions of four great occasions of the Buddha's life: 'The Enlightenment, Great Miracle, The First Sermon and The Descending from Tāvatims $\bar{a}$ seem to be popular for both Mahayanist and Theravada Buddhists. The style of Buddha image is probably dated to the $10^{\text {th }}$ - early $11^{\text {th }}$ century CE.

Group 2, Type 3: Seated Buddha with six stupas, banyan leaf shape

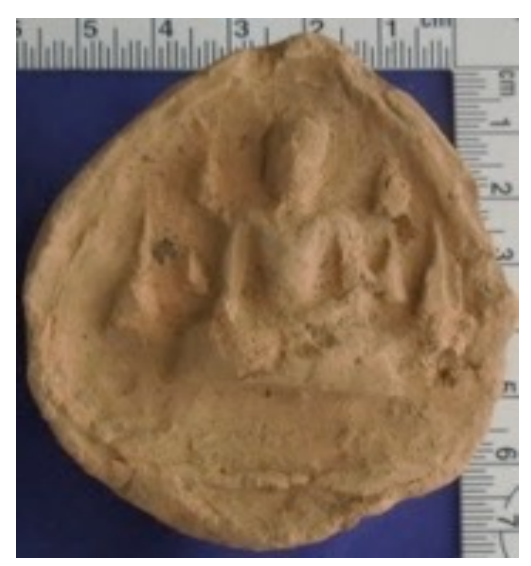

Fig. $11[7.5$ x 6.5 x 1cm]. Source: Khin Ma Ma Mu.

Type 3 is a banyan leaf shape depicting a seated Buddha in a crossed leg position on a (?)lotus throne. The image is in the bhumisparśamudrā flanked by three bell-shaped stupas on each side with a conical shape finial. The rim is decorated with a line of bead-shapes. It is assigned to the $10^{\text {th }}$-early $11^{\text {th }}$ century CE. It may be the locally made due to the roughness of the motifs, or this fuzziness may be due to weathering.

\section{Group 2, Type 4.1: Umbrella finial type}

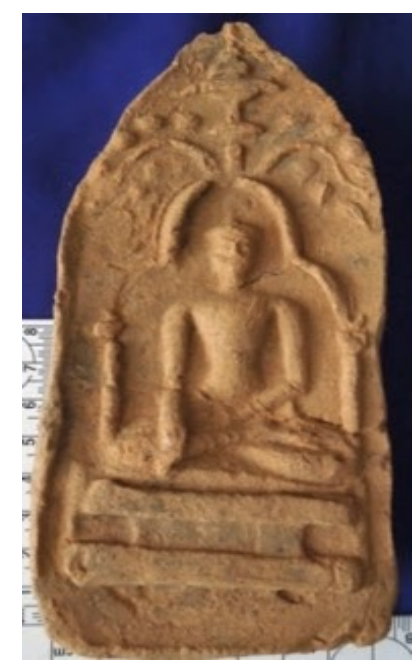

Fig. 12 Umbrella finial supported by long pole without śikhara and stupas. [14.5 x 6.5 x $1.5 \mathrm{~cm}]$. Source: Khin Ma Ma Mu. 
Type 4.1 is rectangular in shape with a pointed top. Buddha is depicted with an elongated body and pointed ushnisha (hair knot) seated in cross-legged position in bhümișparśamudrā on the double plain pedestal. Buddha sits inside a niche or trefoil arch surmounted by the umbrella (with three chattravali) supported by a long pole which rises to the top finial. From the top of the tamikai (the back part of the seat) appear the branches and leaves of Bodhi tree. The style is probably dated to the $10^{\text {th }}$ century before King Aniruddha of Bagan and may be a local product of Thaton.

\section{Group 2, Type 4.2: Umbrella finial type, Buddha with twenty stupas}

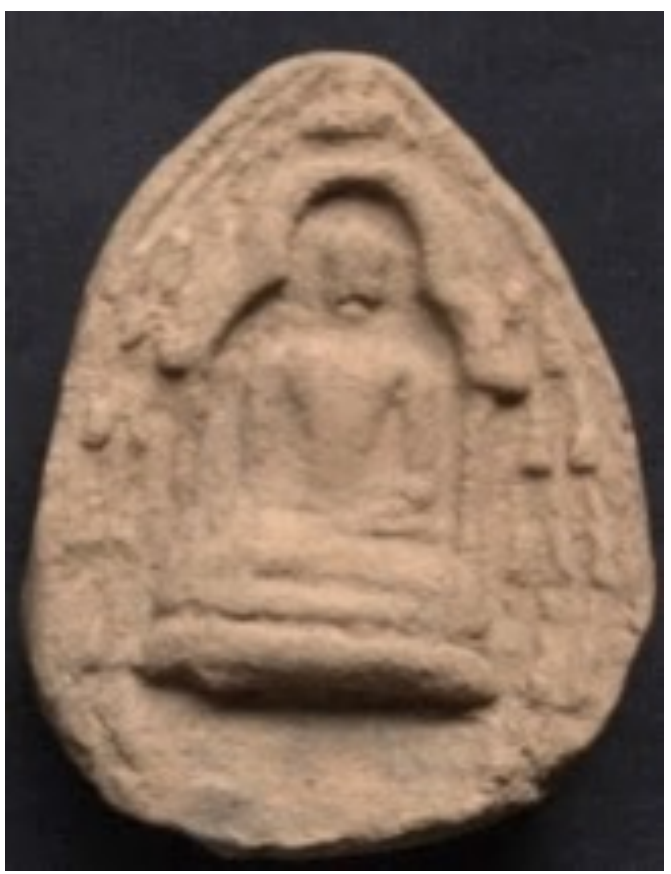

Fig. 13 Umbrella finial type, Buddha with twenty stupas. [6.7 $\mathrm{cm} \times 4.6 \mathrm{~cm} \times 1.7 \mathrm{~cm}]$. Source: U San Win.

The shape of type 4.2 is ovoid. The Buddha sits in a cross-legged position on the double lotus throne with the right hand pointing downwards in the "witness" attitude (bhümiparśamudrā). The image is flanked by ten stupas, with umbrella on the niche. There might have been the Buddhist formula Yedharma inscribed under the throne but it has disappeared now.

The tablet from Catubhumikka monastery may be compared with the tablets from Sind province, India (now in Pakistan) dated to the $7^{\text {th }}-8^{\text {th }}$ century CE according to the orthography of the inscription (Cousens 1914: 88, P1. XXXIX, Fig. e). Other comparisons are to a tablet $\left(9^{\text {th }}-10^{\text {th }} \mathrm{CE}\right)$ from Kyaikkatha mound No. 2, in KyaikHto Township, Mon state (Archaeology Office 1986) and a tablet from Khubua,Thailand which came from Nalanda, India to Khubua in 956 CE (Bhumadhon and Pongpanich 2015: 395, Figs. 9 and 20). The earliest type tablet from Sind has only two stupas at each side of Buddha and later similar ones had more stupas up to ten. Stylistically, Type 4.2 is probably dated to the $10^{\text {th }}$ or the early $11^{\text {th }}$ century CE before the reign of King Aniruddha of Bagan. 
Group 2, Type 4.3: Umbrella finial type, Buddha with ten stupas on each side

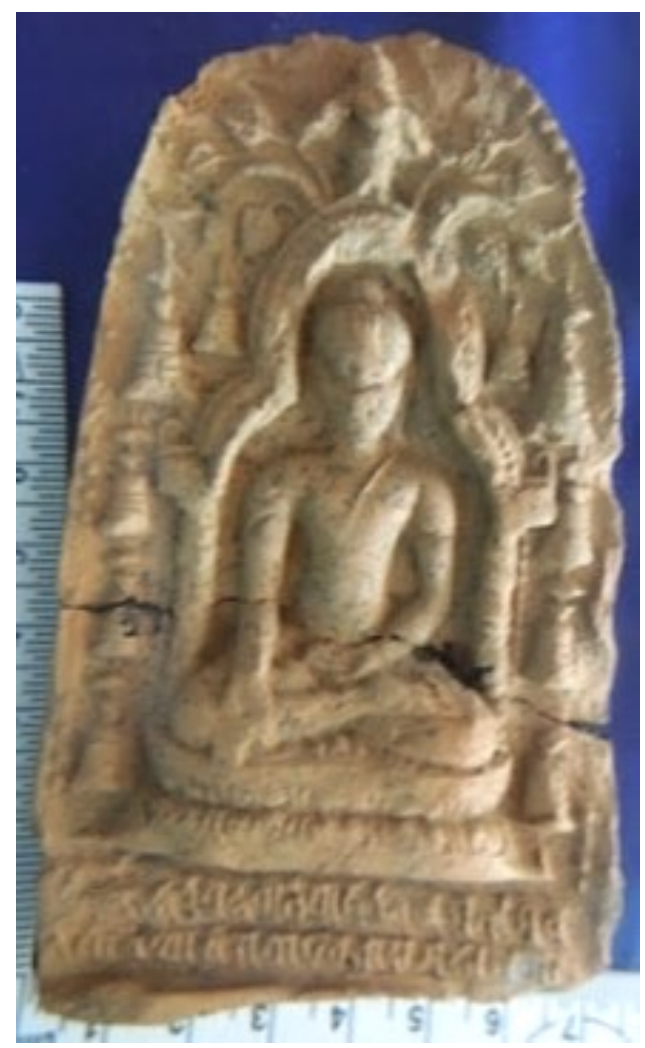

Fig. 14 Umbrella finial type, Buddha with ten stupas on each side. Note the Yedhamā stanza in Nagari script at the bottom of tablet. [10.5 x 7 x $1.5 \mathrm{~cm}$ ]. Source: Khin Ma Ma Mu.

The shape of Type 4.3 is a rectangular base and an almost rounded top. Buddha sits in cross legged position with the bhümisparśamudrā. The image is inside a trefoil arch surmounted by parasol, from which Bodhi leaves and branches emerge. There are five stupas at the both sides of pillar and arch and two-line inscriptions in ancient Nāgari, probably the Yedhamā verse, inscribed at the bottom.

It can be compared with the tablet of 'Sri Bañano' which has six lines inscribed in Pyu script at the back, found from Bagan. It has the Yedhammā stanza in Nägari script at the bottom but the languages are mixed with Sanskrit and Pali datable to the $11^{\text {th }}$ century CE (Mya 1961: Vol. I, 23-24, Figs. 29). The Group 2, Type 4.3 tablet is also similar to the tablet with four stupas from Śriksetra before Bagan period (Mya 1961: Vol. II, 19, Fig. 23).

This Type 4.3 tablet also has the Yedhammā stanza in Nāgari script at the bottom but no initial of the donor was found on the reverse of the votive tablet. It seems to be earlier than that of the Sri Bañano tablet and contemporary with the tablet found from Śriksetra mentioned above. One scholar Dr Nan Hlaing (2016) said that the Yedhama stanza is inscribed in Pallava script and datable between $5^{\text {th }}-10^{\text {th }}$ centuries CE. However, the Yedhamā verse inscribed in Nāgari script may not be earlier than $9^{\text {th }}$ $10^{\text {th }}$ century CE (Nan Hlaing 2016: Fig. 34). 
Group 2, Type 5: Stupa finial, Buddha with two stupas inside niche

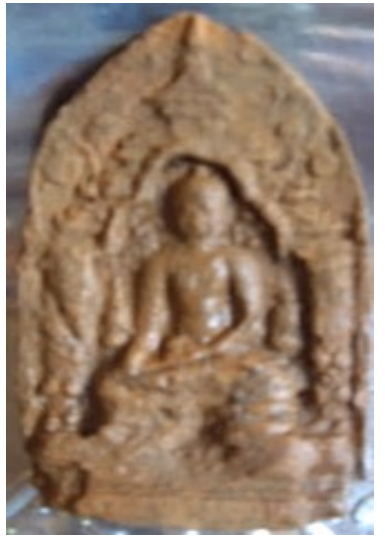

Fig. 15 Group 2, Type 5 [8.1 x 4.8 x 1.5cm] (seen while wet). Source: Khin Ma Ma Mu.

The shape of Type 5 has a rectangular base and a slightly pointed top. It depicts the Buddha in bhümisparśamudrā sitting in a cross-legged position on the Khou nan: gjou: throne (projecting corners on throne). The Buddha has a faint smile. Each miniature stupa flanks the Buddha inside the niche. Banyan leaves come out behind the both sides of stupa finial. There is a flower above the shoulders of Buddha. The 'stupa finial' is on the harmika or relic chamber of the Sri Lanka type and is not the same as seen on the Maha Bodhi śikhara of Bodh Gaya. The pediment can be called a cetiya or stupa finial(calac). The pillars of pediment are decorated with turnery or with the thick floral motifs which may be compared with the votive tablet found near Nan Phaya, Myinkapar, Bagan (Mya 1961: Vol. I, 68, Fig. 102). It may be dated to the $10^{\text {th }}$ century CE.

\section{Group 2, Type 6.1: Bodhi śikhara with amalaka finial, without stupa}
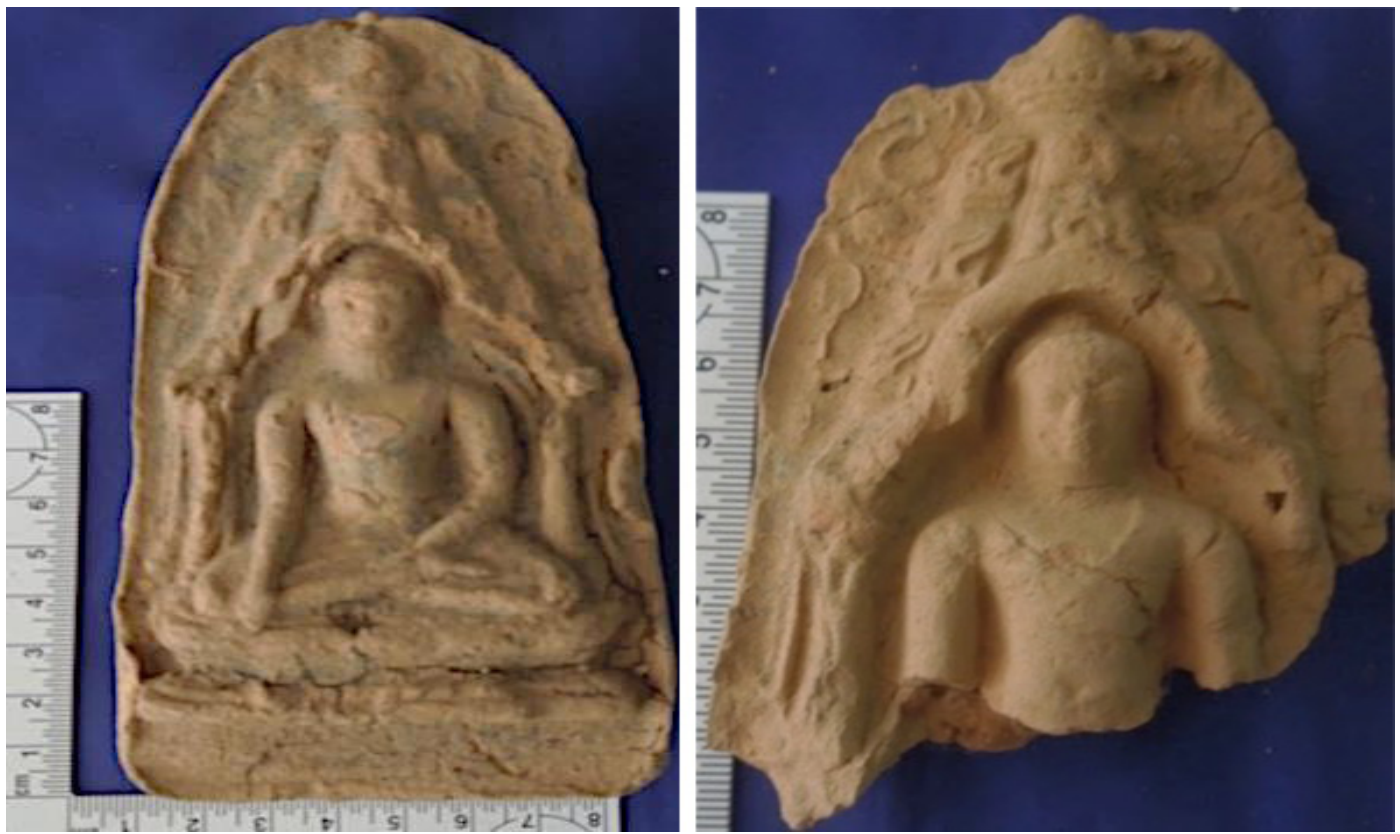

Fig. 16 Type 6.1 Left: [ $15 \mathrm{~cm}$ height x $8 \mathrm{~cm}$ width]. Right: Fragment of votive tablet. Source: Khin Ma Ma Mu. 
Catubhumikka votive tablet Group 2, Type 6.1 has a rectangular base and a rounded arch top. The clarity of the facial expression resembles faces depicted on Indian sculpture suggesting it may have been imported from India. The Buddha sits in bhümisparśamudrā and a cross-legged position (dhyānāsana) on the (?)lotus throne above the high plain pedestal inside the niche surmounted by a sikhara recalling the Mahabodhi stupa of Bodh Gaya (Than Tun 1978). It is decorated with curvilinear flower patterns which rise to the amalaka and the top finial. There are flying pennants (tam khon) emerging from the top finial. Comparing the upper fragment of same tablet (Fig. 16, right), the curvilinear flowers patterns are also seen clearly beside the Bodhi sikhara.

The shape of Buddha's face is oval with a prominent nose and open eyes looking straight, rather than the more usual downcast expression. The top knot (usnisa) is not high but visible and the hair curls are modelled like beads. The robe is transparent on the body, made visible by a line on the left chest and shoulder. The chest and arms are full and fit and the navel is visible, comparable to $9^{\text {th }}-10^{\text {th }}$ century CE in Pala art. This type came probably from Bengal or Bihar, the eastern school of Benares.

Group 2, Type 6.2: Sikhara with six stupas type

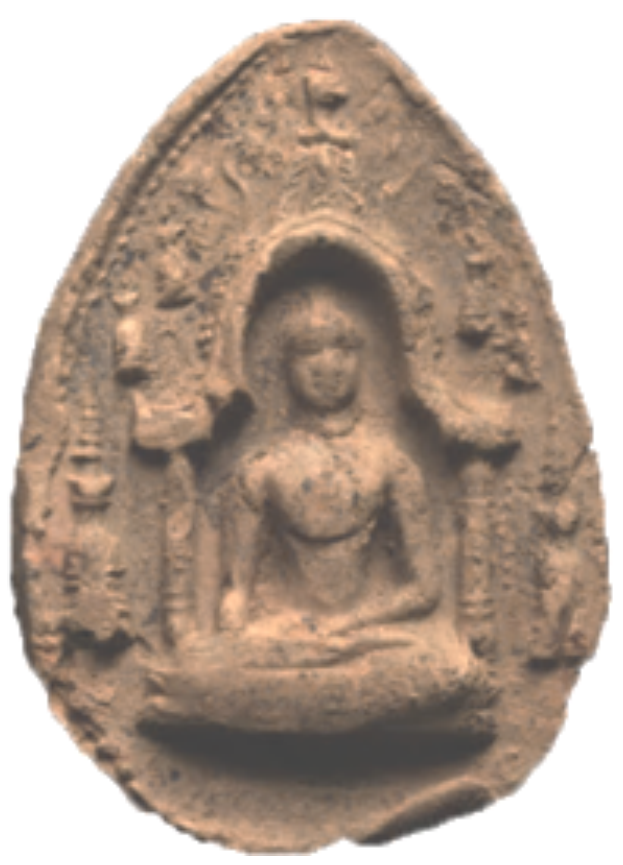

Fig. 17 Type 6.2. [8.1 cm x $6.8 \mathrm{~cm}$ x 1.2cm] Source: U San Win.

Votive Tablet Type 6.2 has a banyan leaf shape. It depicts the Buddha in dhyānāsana on the double lotus throne and with bhümisparśamudrā. He is seated in a niche surmounted by a sikhara and amalaka finial. The arch and niche are flanked by three stupas each with banyan leaves emerging behind the sikhara. There may have been a Yedhama $\bar{a}$ stanza in two lines inscribed under the throne, and there is no evidence of Mon scripts at the back. 
It is dated to the $10^{\text {th }}$ century according to the bell shape style of the three stupas with five chattravali. It may be compared with similar tablets from Bodh Gaya with eight stupas and examples with five stupas from Śriksetra and Bagan (Cunningham 1892/1961: 51, Fig. XXIV e; Mya 1961: Vol. II, Figs. 89-90). It is probably datable to be $10^{\text {th }}$ century CE and not later than the early $11^{\text {th }}$ century CE.

\section{Group 2, Type 6.3: Sikhara finial type with four stupas}
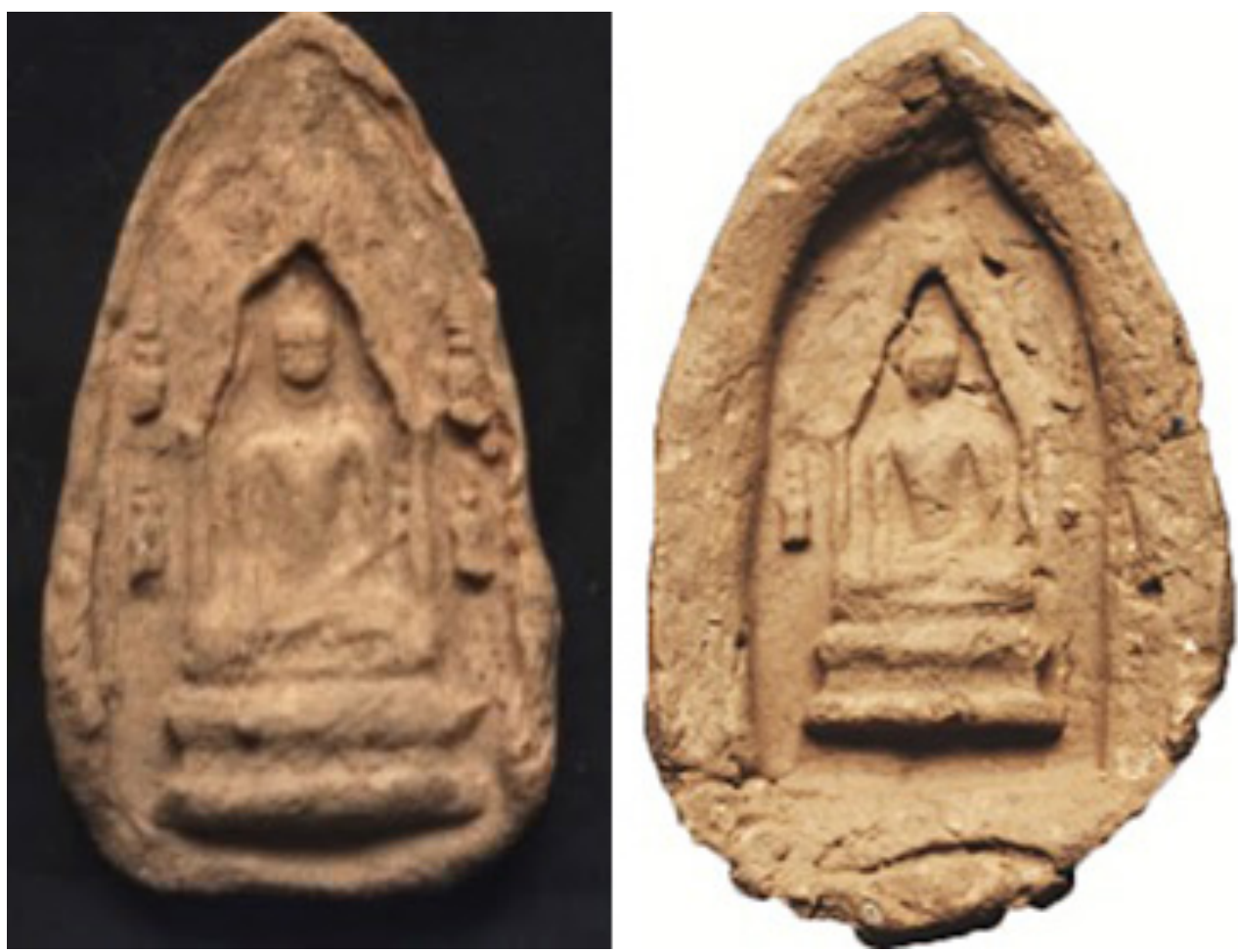

Fig. 18 Group 2, Type 6.3. Left: [9 x 5.6 x $1.5 \mathrm{~cm}$ ]. Right: [12.2 x 7.5 x $3.2 \mathrm{~cm}$ ]. Source: U San Win.

Type 6.3 has an almost rectangular base and pointed arch top. The right tablet of Figure 18 has a thick rim. The tamkai is with the sikhara and umbrella finial. Buddha sits in dhyānāsana with bhümisparśamudrā on the high double lotus throne inside the triangular arch tamkai. There are two stupas beside the pillar and a triangular arch surmounted by a sikhara and umbrella. It seems to be locally made due to the innovative triangular arch and may be datable to the $10^{\text {th }}$ century CE. 
Group 2, Type 6.4: Śikhara with trefoil arch, Buddha with twelve stupas
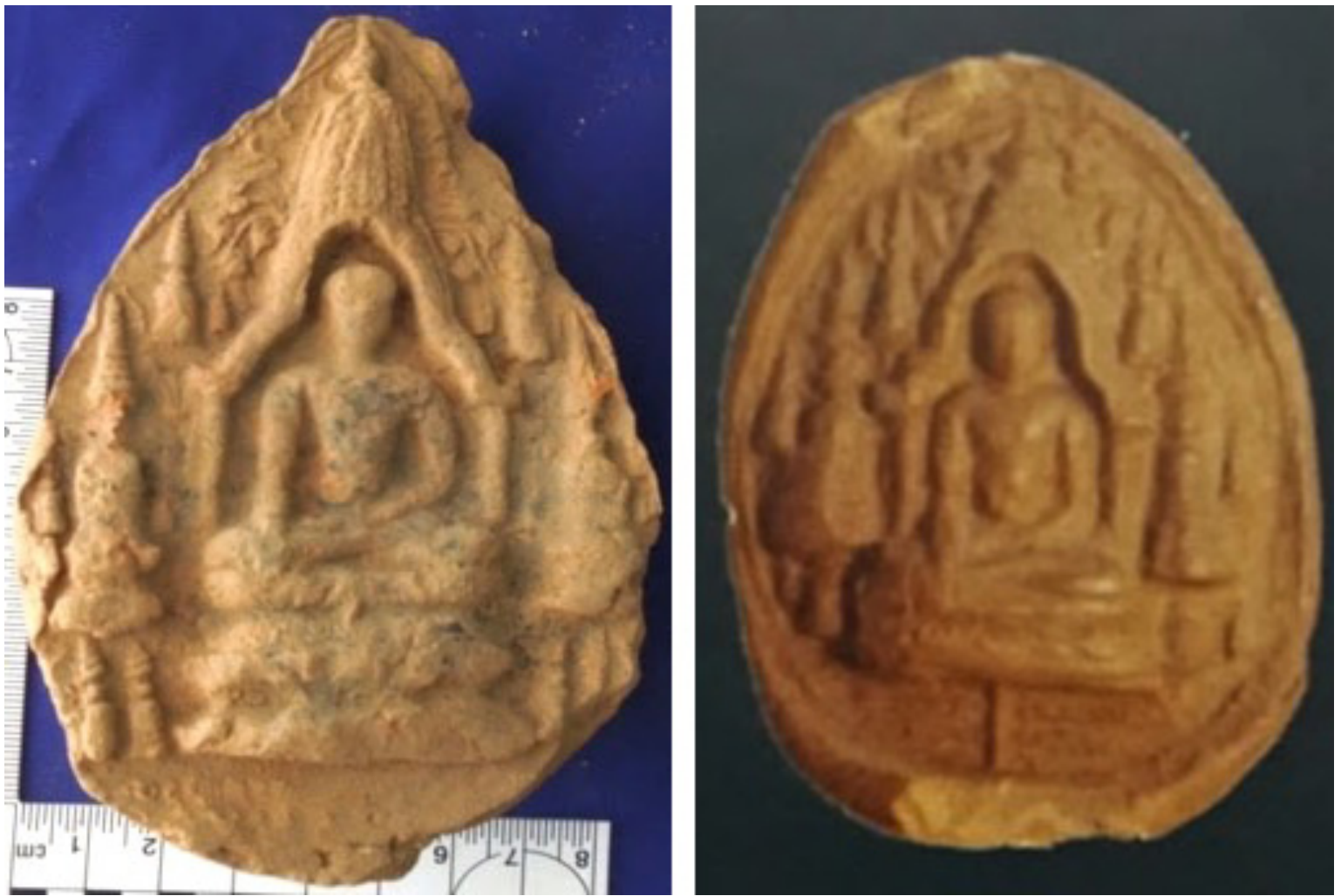

Fig. 19 Group 2, Type 6.4. Left: [12 x 8.8 x 2cm]. Right: [11.5 x 9 x $0.7 \mathrm{~cm}$ ], Nalanda,(six stupas), $9^{\text {th }}-10^{\text {th }}$ century CE. Source: Khin Ma Ma Mu.

Type 6.4 is banyan-leaf shaped. The Buddha is seated in dhyānāsana on the high double lotus throne and with the bhümisparśamudrā within a trefoil niche surmounted by a sikhara and amalaka finial. Both sides of the throne and tamkai are flanked by bell-shaped stupas, a total of six. Banyan leaves emerge from the Bodhi sikhara. There may be a three-line inscription under the throne. The tablet is datable to the $10^{\text {th }}$ century according to the bell-shaped stupa style. Other similar tablets with twelve stupas $\left(9^{\text {th }}-10^{\text {th }}\right.$ century CE) have been found at Nalanda, in Bihar, east India (Krishnan 2010: 76, Fig. 10865). Therefore, it is probably datable to be the $10^{\text {th }}$ century $\mathrm{CE}$ and not later than the early $11^{\text {th }}$ century $\mathrm{CE}$. 
Group 2, Type 6.5: Sikhara with twenty stupas

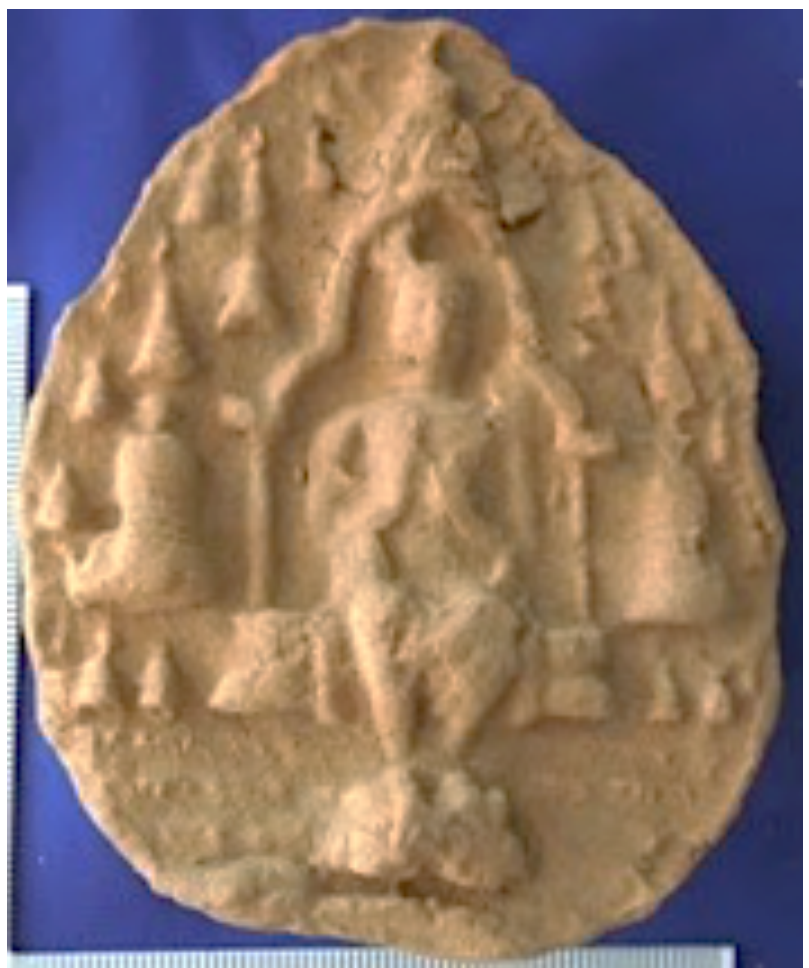

Fig. 20 Group 2, Type 6.5. [11 x 8.5 x $2.5 \mathrm{~cm}]$ Source: Khin Ma Ma Mu.

Votive tablet Type 6.5 is banyan-leaf shape. Buddha sits in bhadrāsana with dhamacakrāmudrā on the double lotus throne with his feet placed on a small double lotus pedestal. There are ten stupas at each side of the pillars and the Bodhi sikhara is raised to the amalaka and top finial. Five lines inscribed in Nägari script of the yedhamma stanza are beside the feet of the Buddha and under the throne. It is probably datable to the $10^{\text {th }}$ century $\mathrm{CE}$ and not later than the early $11^{\text {th }}$ century $\mathrm{CE}$.

Comparable examples are seen from Śriksetra and Bagan $(12.7 \times 10.1 \mathrm{~cm})$, mound no. 1 at Kyaikkatha (10x $10 \mathrm{~cm})$ from 1986 excavations, and at the new building of the State Middle School at Thaton (10.1 x 7.6cm) (Mya 1961: Vol. II, 37, Fig. 8788). These may have been made at Bodh Gaya (Cunningham 1892/1961: 51, Fig. XXIV c). Other comparable examples have been documented at Khubua, Thailand with three lines of Yedhama a stanza in Nāgari script under the throne, dated to 1500 $\mathrm{AB}(956 \mathrm{CE})$, it was originally from Nalanda, India, and this tablet is now in Rajbhuri National Museum², Bangkok Fine Arts Department (Bhumadhon and Pongpanich 2015: 395, Fig. 9.20).

It can also be compared with the tablet from Mirpur-Khas stupa, Sind province which was two hundred years earlier than those of Bodh Gaya. The tablet from Sind depicts the niche surmounted by umbrella instead of a sikhara. The cetyia (stupa) types are however, exactly the same. The Sind example has just two stupas, referring to

\footnotetext{
${ }^{2}$ Thai Scripts were translated by San Win, Member of Myanmar Historical Research Department, Ministry of Religious Affairs and Culture.
} 
Buddha's First Sermon as is indicated by the two deer visible under the inscription. There are three lines of the Yedhamma besides the feet are datable to the $7^{\text {th }}$ or $8^{\text {th }}$ century CE. Associated finds of Arab coins are dated to 715 CE (Cousens 1914: 88, P1. XXXIX, Fig. e). The origin of this type is supposed to be come from Bodh Gaya and Sind province, India to Thaton, KyaikKhathar, Śriksetra, Bagan and Thailand in $10^{\text {th }}-11^{\text {th }}$ century CE.

\section{Group 3}

\section{Group 3 Type 1 Episodes of the Buddha's life}

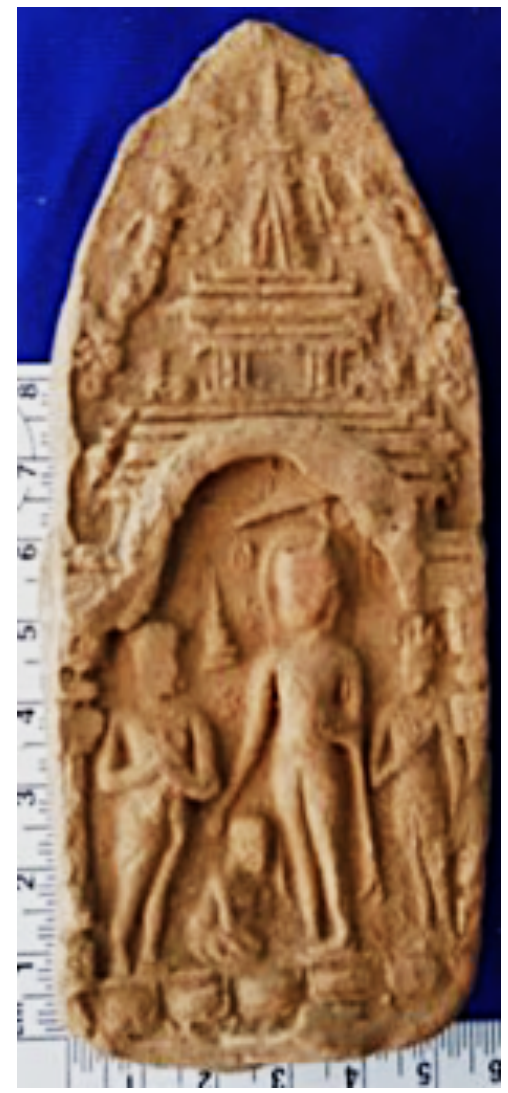

Fig. $21[11.5 \times 5 \times 1 \mathrm{~cm}]\left(9^{\text {th }}-10^{\text {th }}\right.$ century CE). Source: Khin Ma Ma Mu.

Group 3, Type 1 has a rectangular base, arched top and is rimless. To date, this votive tablet type has not been found elsewhere in Myanmar. It depicts the Descent from Tavatims $\bar{a}$. The pillars partially remain to support the rounded arch on which a harmika or relic chamber is placed between the lines indicating the receding roof tiers. Above this, the sikhara and the amalaka decorated with floral motifs is surmounted by the top vajra finial. The leaves and branches of the Bodhi tree emerge from the both sides of finial.

Beside the harmika is each seated lion facing outwards at the both corners of the lower part of the receding terraces. The lion figure is used in the tablets of Śriksetra since the Pyu period. Some Pyu tablets depict a pair of standing lions and other mythical creatures on the either side of Buddha (Mya 1961: Vol. II, Figs. 10-14). That 
custom continues until now of placing lions or mythical creatures at the entry of a stupa.

From top to bottom, each crowned deva or deity has the inner hand raised holding up an indistinct object and the outer hand hanging down. Floral motifs are below their feet. The figures on either side of the sikhara are depicted descending from the celestial realms. A miniature stupa and three flowers are also arranged at the space of the front face inside the tamkai.

The left hand of the standing Buddha is probably holding up the rim of the robe and right hand shows the abhayamudrā on the head of monk AggaSāvakaShin Sāriputtarā. The robe of Buddha depicts transparent and typical of the Pala period $\left(9^{\text {th }}-10^{\text {th }}\right.$ century CE). Above the head of Buddha is an umbrella, its pole held by in the right hand of a standing crowned Indra on the pedestal at the left side of Buddha. AggaSāvakaShin Sāriputrā is kneeling on the two pedestals with the clasped hands (namaskāramudrā) below the Buddha's feet. The head of AggaSāvaka is shaven. Brahmā is also depicted in namaskāramudrā standing on the pedestal at the right side of Buddha.

Group 3 Type 2: Eight Episodes of Buddha's life, trefoil niche with 3 poles supporting umbrellas

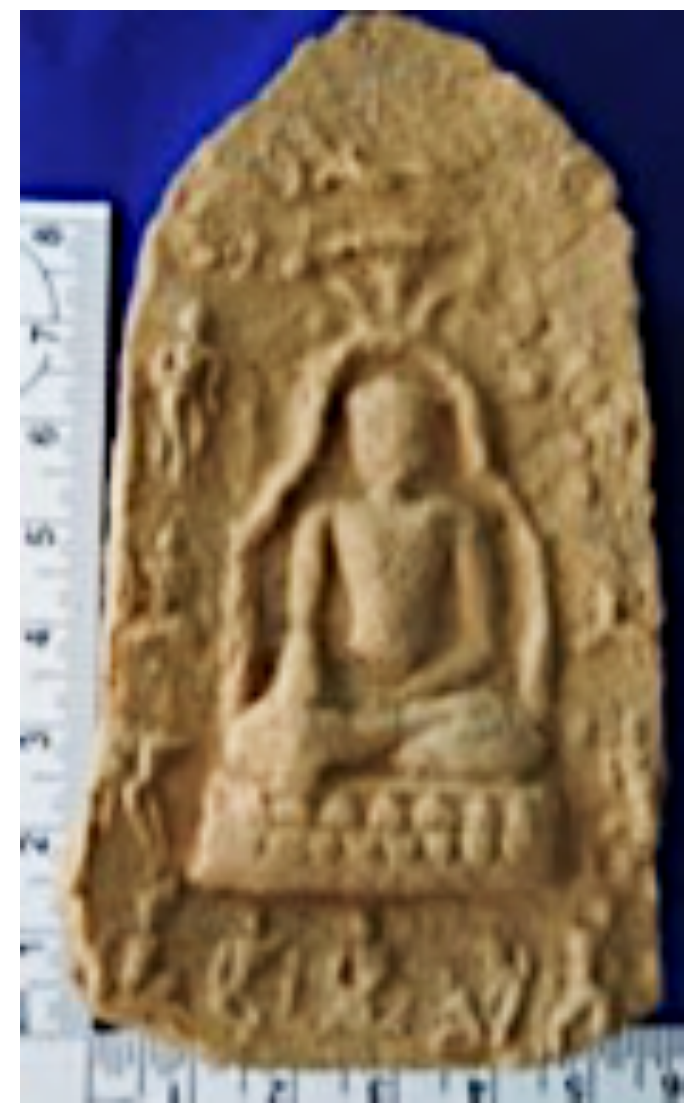

Fig. $22[12 \times 7.5$ x 1.5cm]. Source: Khin Ma Ma Mu.

Votive tablet Group 3, Type 2 has a rectangular base and an arched top. It depicts the Eight Episodes of the Buddha's Life. It may belong to the $10^{\text {th }}$ - early $11^{\text {th }}$ century 
CE. The Catubhummika tablet shows the attack of Māra's army under the double lotus throne. This type has not yet been found at Śriksetra and Bagan. The upper portion of this tablet is comparable to a fragment from Bagan (Luce 1969-1970: Vol. II, 60 and Vol. III, 69). Other tablets of Bagan show three elephant-riders of Māra attacking below the Mahaprinivanna or passing over the top of the Buddha (Luce 1969-1970: Vol. I, 153 and Vol. III, Pl. 74d).

\section{Group 3, Type 2: Eight Episodes of Buddha's life}

\begin{tabular}{|c|c|c|}
\hline Mourner & $\begin{array}{l}\text { (1) Mahāparinirvāna } \\
\text { head to the right }\end{array}$ & \\
\hline Ānanda & $\begin{array}{c}3 \text { poles supporting } \\
\text { umbrellas }\end{array}$ & $\begin{array}{l}\text { Two kneeling figures with } \\
\text { raised hand }\end{array}$ \\
\hline $\begin{array}{c}\text { Kneeling figures with raised } \\
\text { hand }\end{array}$ & Trefoil arch & \\
\hline $\begin{array}{l}\text { (8) Nālāgiri elephant scene } \\
\text { (standing Buddha with a } \\
\text { monk) }\end{array}$ & \multirow{2}{*}{$\begin{array}{l}\text { (5) Seated Buddha in } \\
\text { dhyānāsana and } \\
\text { bhümisparśamudrā } \\
\text { (Enlightenment) }\end{array}$} & $\begin{array}{c}\text { (2) Descent from Tāvatimesa } \\
\text { (Buddha between Indra and } \\
\text { Brahmā) }\end{array}$ \\
\hline $\begin{array}{l}\text { (7) Three Seated Buddha in } \\
\text { dharmacakramudrā } \\
\text { (First Sermon) }\end{array}$ & & $\begin{array}{l}\text { (3) Three Seated Buddha in } \\
\text { dharmacakramudrā } \\
\text { (Twin Miracle) }\end{array}$ \\
\hline $\begin{array}{l}\text { (6) Nativity (Māyādevi and her } \\
\text { sister PajāpatiGotami ) }\end{array}$ & & $\begin{array}{l}\text { (4) Parileyyaka Retreat } \\
\text { (Buddha in bhadrāsana) }\end{array}$ \\
\hline
\end{tabular}

Table 3 Key to episodes ( 1 to 8 ) arranged in a clockwise direction.

\section{Group 3, Type 3A and 3B: Trefoil niche with Sikhara and Amalaka finial}

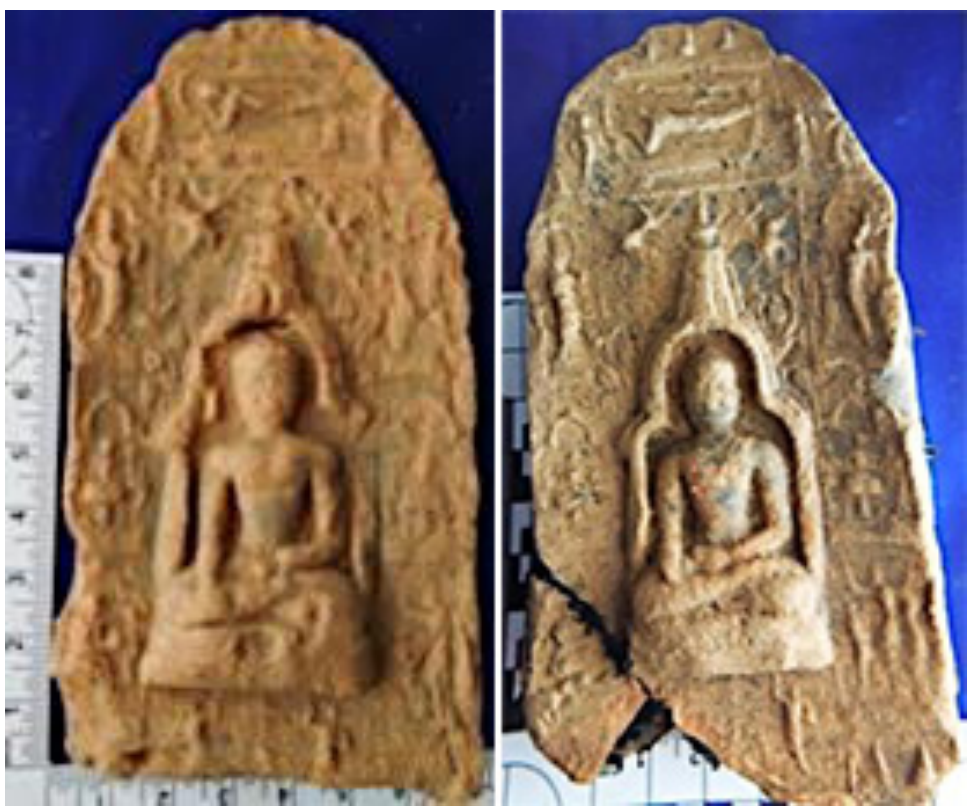

Fig. 23 Left: 3A [12 x 7.2 x 1cm]. Right: 3B [12 x 7 x 1cm]. Source: Khin Ma Ma Mu. 
There are three stupas at the top above the Parinirvāna scene, with the Buddha's head placed to his right (3A) and to the left hand (3B). There is same arrangement of the eight episodes seen at Bagan and Thaton but sometimes they change the place to right or left side for the arrangement of Nativity scene and Parileyyaka retreat episode.

At the top is displayed the passing on or mahaparinirvanna with the head of Buddha placed on his right hand. Type 3B shows the head place on his left hand. This changing arrangement is significant. The Enlightenment scene or illumination (sambodhi) is always placed in the centre. Buddha is looking straight ahead. He sits in bhümisparśamudrā and dhyānāsana on a double lotus throne under the trefoil abacusarch with sikhara, amalaka and lotus bud finial. At the middle lower tier is the Buddha Triad (three seated Buddhas) which represents both the First Sermon and the Twin Miracle.

From top to bottom, the second row left depicts the taming of the mad elephant Nālāgiri or Ratanapāla and at the right the Descent of Buddha from the heaven of the thirty-three gods. These two episodes are placed at the either side of sikhara. In the third row left is the first sermon at Benares and the Miracle of Śāvasti scene at the right. In the centre shows the Enlightenment with the Buddha as the main figure. There is a depiction of Māra's army or daughters added at the bottom of tablets at CatubhummikaThaton which has not seen at the tablets of Bagan. However, some tablets from Bagan were inscribed in Nāgari or Mon scripts with the Yedhamā stanza or the names of donor and wishes (Luce 1969-70: Vol. III, 70-72, 74, Figs. a, c, d; Mya 1961: Vol. I, 13a, 45a, 51).

In Type $3 \mathrm{~A}$ and $3 \mathrm{~B}$, the bottom left shows the presentation of honey to Buddha by the monkey at Vaiśāli and the bottom right depicts the birth. The birth shows Māyādevi standing under the aśāla tree clasping the neck of a female to her proper left, her sister Prajāpati Gotamī and the child; and the infant Buddha issuing from her proper right. These two episodes were changed from the left or right according to the artist or the donor's wishes.

There were also changes of episodes in arrangement of type $3 \mathrm{~A}$ and $3 \mathrm{~B}$ with the nativity and the retreat of honey rice placed on the left or right. Type 2 and type 3B are in the same arrangement for the nativity at the left bottom and Parileyyaka Retreat at the right. 
Group 3, Type 3A: Eight Episodes of Buddha's life

\begin{tabular}{|c|c|c|}
\hline $\begin{array}{l}\text { Mourner } \\
\text { one standing figure Ānanda } \\
\text { and ?one seated figure }\end{array}$ & $\begin{array}{l}\text { (1) Mahāparinirvāna } \\
\text { head to the right } \\
\text { sikhara with amalaka } \\
\text { finial }\end{array}$ & One standing figure \\
\hline $\begin{array}{c}\text { (8) Nālāgiri elephant scene } \\
\text { (standing Buddha with a } \\
\text { monk) }\end{array}$ & $\begin{array}{l}\text { Trefoil arch } \\
\text { (5) Seated Buddha in }\end{array}$ & $\begin{array}{c}\text { (2) Descent from Tāvatimsa } \\
\text { (Buddha between Indra and } \\
\text { Brahmā) }\end{array}$ \\
\hline $\begin{array}{l}\text { (7) (?Three) Seated Buddha } \\
\text { in dharmacakramudrā } \\
\text { (First Sermon) }\end{array}$ & $\begin{array}{l}\text { dhyānāsana and } \\
\text { bhūmisparśamudrāa } \\
\text { (Enlightenment) }\end{array}$ & $\begin{array}{c}\text { (3) (?Three) Seated Buddha in } \\
\text { dharmacakramudrā } \\
\text { (Twin Miracle) }\end{array}$ \\
\hline $\begin{array}{l}\text { (6) Parileyyaka Retreat } \\
\text { (Buddha in bhadrāsana) }\end{array}$ & & $\begin{array}{l}\text { (4) Nativity (Māyādevi and her } \\
\text { sister PajāpatiGotami), one figure } \\
\text { may be Brahmā or a baby }\end{array}$ \\
\hline
\end{tabular}

Table 4 Key to episodes ( 1 to 8 ) is arranged in a clockwise direction.

Group 3, Type 3B: Eight Episodes of Buddha's life

\begin{tabular}{|c|c|c|}
\hline & Three Stupas & $\begin{array}{c}\text { A standing figure } \\
\text { (?Shin Mahākasapa) }\end{array}$ \\
\hline Two Mourners & $\begin{array}{c}\text { (1) Mahāparinirvāna head to the } \\
\text { left }\end{array}$ & \\
\hline $\bar{A}$ nanda in standing position & sikhara with amalaka finial & \\
\hline $\begin{array}{c}\text { (8) Nālāgiri elephant scene } \\
\text { (standing Buddha with a } \\
\text { monk) }\end{array}$ & $\begin{array}{c}\text { Trefoil arch } \\
\text { (5) Seated Buddha in dhyānāsana } \\
\text { and } \\
\text { bhümisparśamudrā } \\
\text { (Enlightenment) }\end{array}$ & $\begin{array}{l}\text { (2) Descent from Tāvatimisa } \\
\text { (Buddha between Indra and Brahmā) }\end{array}$ \\
\hline 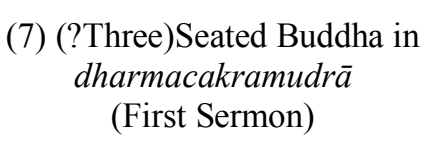 & & $\begin{array}{c}\text { (3) (?Three) Seated Buddha in } \\
\text { dharmacakramudrā } \\
\text { (Twin Miracle) }\end{array}$ \\
\hline $\begin{array}{c}\text { (6) Nativity scene, Māyādevi } \\
\text { and her sister Pajāpati } \\
\text { Gotami) and ? a child to the } \\
\text { left of Māyādevi }\end{array}$ & & $\begin{array}{l}\text { (5) Parileyyaka Retreat (Buddha in } \\
\text { bhadrāsana) }\end{array}$ \\
\hline \multicolumn{3}{|c|}{ Māra's warriors ( about seven figures ) } \\
\hline
\end{tabular}

Table 5 Serial Number 1 to 8 are arranged in a clockwise direction. 
Group 3 Type 4: Ten Episodes of Buddha's life
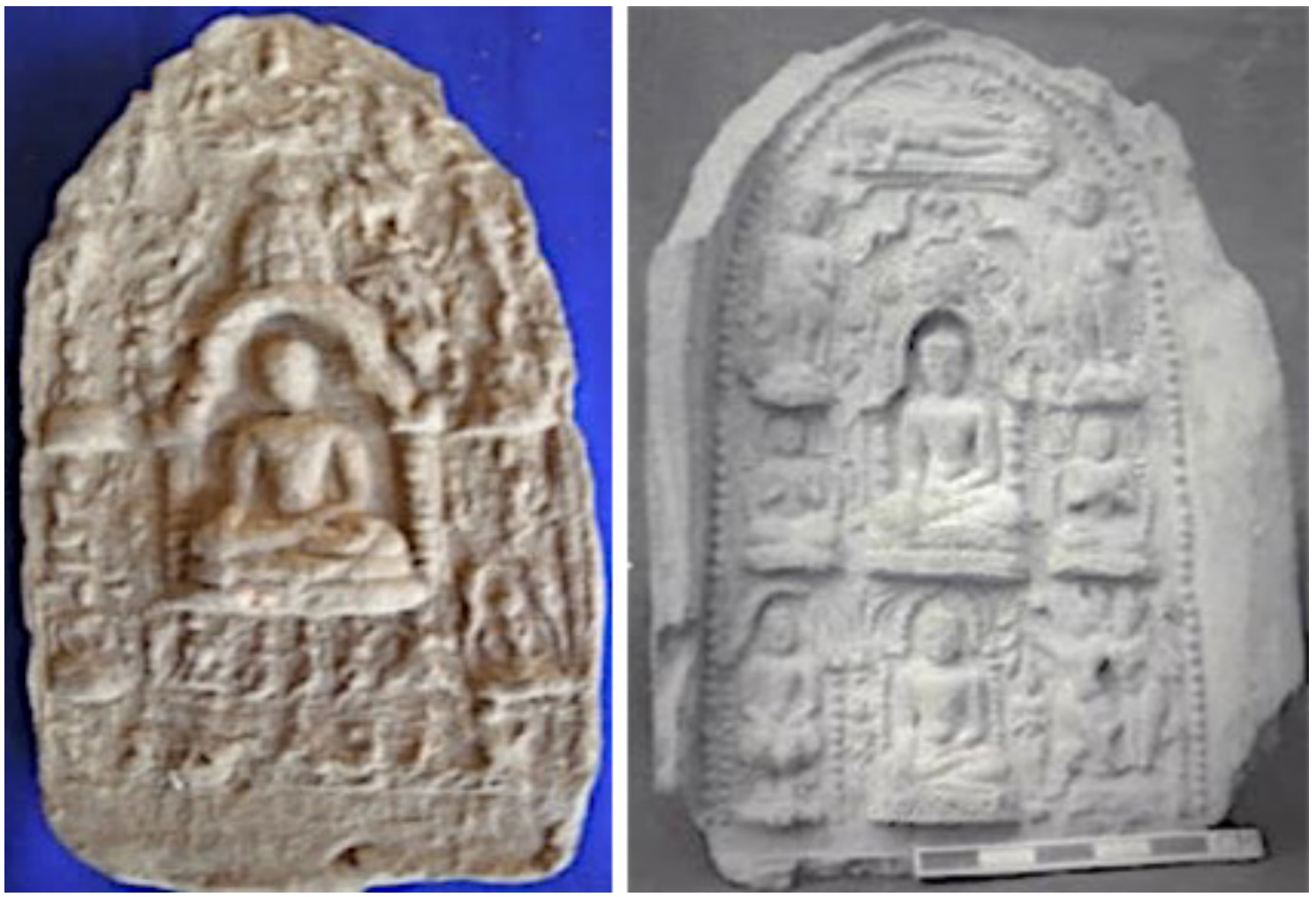

Fig. 24 Left: Group 3 Type 4 [12.5 x 7.5 x 1.5cm]. Right: From Śriksetra, 9 Episodes of Buddha's life. Source: Khin Ma Ma Mu.

\begin{tabular}{|c|c|c|}
\hline & Stupa & \\
\hline & Mourners & \\
\hline 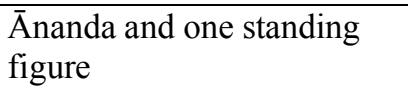 & $\begin{array}{l}\text { (1) Mahāparinirvāna head to } \\
\text { the left }\end{array}$ & Two standing figures \\
\hline $\begin{array}{l}\text { (10) Nālāgiri elephant scene } \\
\text { (standing Buddha with a } \\
\text { monk) }\end{array}$ & $\begin{array}{c}\text { sikhara with amalaka finial } \\
\text { Trefoil arch }\end{array}$ & $\begin{array}{l}\text { (2) Descent from Tāvatimsa } \\
\text { (between Indra and Brahmā) }\end{array}$ \\
\hline $\begin{array}{l}\text { (9) (?Three) Seated Buddha } \\
\text { in dharmacakramudrā } \\
\text { (First Sermon) }\end{array}$ & & $\begin{array}{c}\text { (3) (?hree) Seated Buddha in } \\
\text { dharmacakramudrā } \\
\text { (Twin Miracle) }\end{array}$ \\
\hline $\begin{array}{l}\text { (8) Parileyyaka Retreat } \\
\text { (Buddha in bhadrāsana) }\end{array}$ & $\begin{array}{l}\text { dhyānāsana and } \\
\text { bhūmisparśamudrāa } \\
\text { (Enlightenment) }\end{array}$ & $\begin{array}{l}\text { (4) Nativity scene, Māyādevi and } \\
\text { her sister Pajāpati Gotami) and a } \\
\text { (?)child to the left of Māyādevi }\end{array}$ \\
\hline $\begin{array}{l}\text { (7) Sujata's offering milk } \\
\text { rice }\end{array}$ & & (5) scene of the Dukracrirā \\
\hline & $\begin{array}{c}\text { Māra' daughters (about seven } \\
\text { figures) }\end{array}$ & \\
\hline & $\begin{array}{l}\text { (?)Māra's army or Māra's } \\
\text { attacking (about seven } \\
\text { figures) }\end{array}$ & \\
\hline
\end{tabular}

Table 6 Key to scenes (1 to 10) arranged in a clockwise direction. 
Group 3, Type 4 is the Ten Episodes of the Buddha's Life. It has a rectangular base and an arched top. From top to bottom, at the peak, there is a stupa-like relic casket above the reclining Buddha (Mahāparinirvāna) with unclear figures behind the reclining Buddha. The head of Buddha in the Mahäparinirvāna episode is placed on his left hand. There are two standing figures at the side of Buddha's head, and other mourners are also standing at the feet of Buddha, one of which may be Shin Ānandā. The main Buddha figure presents the episode of Enlightment.

At the first tier, the right side is very clear: the kneeling Shin Sāriputra in namaskāramudrā, is from the episode of Descent from Tāvatimsa. The left side presents the episode of the Nālāgiri elephant. At the second tier, the Buddha Triad is indistinct, possibly the First Sermon at left side and the Twin Miracle at the right side. At the third tier, right side, the Nativity scene is unclear while the left side shows Parileyyaka Retreat.

At the fourth tier, two extra episodes are added: probably an episode of 'Sujata's offering milk rice' is on the left (? an unclear figure of Sujata on the left side of Buddha), and the scene of the Dukracrirā on the right while the ten scenes Andagu steles of Arakan (Rakhine state) represents the episode of the Naga Mucalinda sheltering the Buddha at that place (San Tha Aung 2016: 95, Pl. 78).

Under the throne of main Buddha figure show Māra's daughters at the upper line and Māra's assault in the lower. Below it at the base is an unclear but a two-line inscription can be guessed. Nine episodes depicted on the tablets have been discovered at Śriksetra and Bagan which show only one extra episode - 'the offering of Milk-Rice by Sujātā (see Luce 1969-1970: Vol. III, 61, Pl. 70a-d; Archaeology Department 1969-70). The depiction of ten episodes of Buddha's life on votive tablet has been only discovered at Thaton, Catubhummika monastery except the Andagu stele found at Rakhine. Beside these it is probably datable to the $10^{\text {th }}$ or early $11^{\text {th }}$ century CE.

\section{Conclusion}

The excavated votive tablets of Catubhummika, Thaton provide valuable evidence to support the distinctive Buddhist art and iconography of Thaton from the $9^{\text {th }}$ century $10^{\text {th }}$ century CE. The assemblage generally speaking is not earlier than the $8^{\text {th }}$ century $\mathrm{CE}$ and not later than the early $11^{\text {th }}$ century CE.

The iconography of some tablets is similar to that seen on votive tablets associated with Mahayana sects from Nalanda, Bodh Gaya and Bengal in Pala period. There are similar tablets seen at Sriksetra and Bagan in Myanmar, on the other hand Thailand, Indonesia and Vietnam as well, dated between the $8^{\text {th }}-11^{\text {th }}$ centuries CE. The smallest size of votive tablets is $6.7 \times 4.6 \times 1.7 \mathrm{~cm}$ and the biggest one is $15 \times 8 \times 2 \mathrm{~cm}$. The shapes of tablets are rectangular base and pointed top, rectangular base and rounded top, oval and Banyan leaf (oval with pointed top).

The Mudrās of Buddha are bhümisparśamudrā, dharmacakramudrā, dhyanamudrā (Samadhimudrā ), vitarkamudrā, abhayamudrā and mahākarunikamudrā. The Asanas 
of Buddha are dhyānāsana, Lalitāsana andbhadrāsana. The most popular of mudrā and asana of Buddha are the bhümisparśamudrā and dhyānāsana. The mudrā and asana of Bodhisattva are abhayamudrā, karunamudrā(unclear), MahaRazalilāsana and Lalitāsana (asana of Nimāna Budddha) and virāsana.

The arrangement of the eight episodes is same to those of the tablets of Bagan. However, sometimes the scenes switch to the right or left, notably the Nativity scene and the Parileyyaka retreat episode. The head of the Buddha is alternately inclined to his right or left hand. There is a depiction of Māra's army or daughters added at the bottom of tablets at Catubhummika Thaton which has not seen at Bagan.

Ten episodes of Buddha's life expressed on votive tablets highlight the creativity of donors or artists at Thaton although similar scenes have found at the Andagu steles at Bengal, Rakhine and Bagan. Two more episodes - Dukracariya and offering of Sujata's milk rice - were added to Thaton votive tablets.

The Buddha triad was always placed at the middle lower tier and the episode of Enlightenment always was placed in the centre. The making practise of Buddha Triad is seen at not only eight episodes of the Buddha's life but also just one. Depictions of Māra's army and (or) daughters were often added at the bottom of tablets at Thaton, but have not been found in Śriksetra and Bagan yet.

Most tablets have the Yedhamā stanza in ancient Nāgari scripts and some distinctive figures which are pointed to the date of $9^{\text {th }}-10^{\text {th }}$ century CE. There is no evidence of Mon or Pyu inscribed on the base or back of the tablets though some tablets included Pyu or Mon letters have been found at Bagan in the reign of King Anirudha. Therefore, these Catubhummika tablets are seemed to be earlier than that of King Anirudha or the early Bagan period.

These 1350 votive tablets and fragments of the spouts of libation jars indicate that this place was the sacred Buddhist site because it is very close to the ancient Thaton palace site and famous ShweSaryan pagoda. As a tomb of monk was placed at the centre of all pits from CBK 1 to 8, we had no chance to know what was buried under the tomb. Although we could not excavate under the tomb, I assumed that under the present tomb there would be a chamber and/or a Buddha image placed for worship. All tablets and laterite pillars are now displayed in situ. As a group, they give significant new evidence on the prevalence of Mahayana practices at Thaton from circa the $8^{\text {th }}$ to early $11^{\text {th }}$ century CE.

\section{Acknowledgements}

I owe many thanks to Sayartaw Bhaddanta Tikkhañāna, abbot from Catubhummika monastery who assisted when taking measurements and finding information on the votive tablets. Others whom I would like to thank include Prof. Elizabeth H Moore (SOAS, London; ISEAS Singapore) for her encouragement and suggestions for this paper; U San Win (Member, Historical Research, Ministry of Religious and Cultural Affairs) for textual assistance and translation from Thai; Dr Toe Hla (Member, Historical Research, Ministry of Religious and Cultural Affairs) for suggestions and encouragements; Nan Kyi Kyi Khaing (Phd Candidate, Kanazawa University, Japan) 
and Dr NawYuzana Win (Independent Scholar) who encouraged me to go to Thaton for the study of the votive tablets excavated from Catubhummika monastery, Thaton; and Ngwe Ngwe Soe (Independent Scholar; Department of Archaeology, retired) for her help with word corrections.

\section{References}

Archaeology Office (1969-70) Negative no. 320/15062. Archaeology Department, Ministry of Religious Affairs and Culture Myanmar. Google Scholar search

Archaeology Office (1986) Negative no. 1. Archaeology Department, Ministry of Religious Affairs and Culture Myanmar. Google Scholar search

Bhumadhon, P and Pongpanich, B (2015). The Revitalization of U Thoung and Mae Klong-Ta Chin river basin through beads and early Buddhist evidences. Bangkok: DASTA \& BIA. Google Scholar search

Chirapravati, P (1997) Votive Tablets in Thailand. Kuala Lumpur: Oxford University Press. Google Scholar search

Cœdès, G (1926) Siamese Votive tablets. Trans. WA Graham. Journal of the Siam Society 20(1): 1-24. Google Scholar search

Cousens, H (1909-10) Buddhist Stupa at Mirpur-khas in Sind. Archaeological Survey of India Annual Report 1909-1910: 80-92. Google Scholar search

Cunningham, A (1892/1961) Mahabodhi or the Great Buddhist Temple under the Bodhi Tree at Buddha-Gaya. Varanasi: Indological Book House. Google Scholar search

Duroiselle, Charles (1931) Archaeological Survey of India Annual Report 1927-28. Calcutta: Central Publication Branch. Google Scholar search

Krairiksh, P (1980) Art in peninsular Thailand Prior to the Fourteenth Century CE. Bangkok: The Fine Arts Department. Google Scholar search

Krishnan, GP (2010) On the Nalanda Trail: Buddhism in India, China \& Southeast Asia. Singapore: Asian Civilizations Museum. Google Scholar search

Luce, GH (1969-70) Old Burma- Early Bagan. 3 vols. Locust Valley, New York: J.J. Augustin. Google Scholar search

Manguin, P-Y and Indrajaya, A (2006) The Archaeology of Batujaya (West Java, Indonesia): An Interim Report. In: E Bacus, I Glover, \& V Pigott (eds.) Uncovering Southeast Asia's Past. Singapore: NUS Press, 245-257. Google Scholar search

Moore, EH (2007). Early Landscapes of Myanmar. Bangkok: River Books. Google Scholar search

Mya (1961) Votive tablets of Burma. 2 vols. Yangon: Yangon University Press. Google Scholar search

Myint Aung (1999). The Excavations of Ayethama and Winka (?)Suvannabhumi. In Essays given to Than Tun on his $75^{\text {th }}$ birthday (Studies in Myanma history). Yangon: Innwa Publishing House, 17-64. Google Scholar search

Nan Hlaing (2016) The First Millennium Artefacts of Suvannabhumi, Terracotta Votive Tablets of Thaton. Mawlamying: Bhadradevi Books. Google Scholar search

Nyunt Han and Kyaw Oo Lwin (2015) Archaeological Findings and Researches at Early Rakhine: Ancient Cities in Myanmar. In NH Tan (ed.) Advancing Southeast Asian Archaeology 2013: Selected Papers from the First SEAMEO SPAFA International Conference on Southeast Asian Archaeology, Chonburi, 
Thailand 2013. Bangkok: SEAMEO SPAFA, 153-161, 189-198. Google Scholar search

Temple, RC (1894). Notes on Antiquities in Ramannadesa (The Talaing country of Burma). Bombay: Education Society's Steam Press. Google Scholar search

Revire, N (2012) A Comprehensive Study of Bhadrasana Buddha Images from First Millennium Thailand. Rian Thai, International Journal of Thai Studies 5: 95152. Google Scholar search

San Tha Aung (2016) The Buddhist Art of Ancient Arakan, an Eastern Border State beyond Ancient India, east of Vanga and Samatata. $2^{\text {nd }}$ ed. Yangon: Unity Publishing House. Google Scholar search

San Win (2015). Research on Suvam abhümi.Yangon: Susumi Press. Google Scholar search

Than Tun (1978) History of Buddhism in Burma AD1000-1300. Rangoon: Burma Research Society. Google Scholar search

U Nyanawara (2014) Myanmar-English Encyclopedic Dictionary of Mahāyāna Buddhist Terms. Yangon: ThuKhi Press. Google Scholar search 